Review Article

\title{
Calcium Signaling in the Ventricular Myocardium of the Goto-Kakizaki Type 2 Diabetic Rat
}

\author{
L. Al Kury $\mathbb{D}^{1},{ }^{1}$ M. Smail, ${ }^{2}$ M. A. Qureshi, ${ }^{2}$ V. Sydorenko, ${ }^{3}$ A. Shmygol $\mathbb{D},{ }^{2}$ M. Oz, ${ }^{4}$ J. Singh $\left(\mathbb{D},{ }^{5}\right.$ \\ and F. C. Howarth iD ${ }^{2}$ \\ ${ }^{1}$ College of Natural and Health Sciences, Zayed University, Abu Dhabi, UAE \\ ${ }^{2}$ Department of Physiology, College of Medicine \& Health Sciences, UAE University, Al Ain, UAE \\ ${ }^{3}$ Department of Cellular Membranology, Bogomoletz Institute of Physiology, Kiev, Ukraine \\ ${ }^{4}$ Department of Basic Medical Sciences, College of Medicine, Qatar University, Doha, Qatar \\ ${ }^{5}$ School of Forensic \& Applied Sciences, University of Central Lancashire, Preston, UK \\ Correspondence should be addressed to L. Al Kury; lina.alkury@zu.ac.ae
}

Received 18 October 2017; Revised 16 January 2018; Accepted 8 March 2018; Published 10 April 2018

Academic Editor: Kim Connelly

Copyright (c) 2018 L. Al Kury et al. This is an open access article distributed under the Creative Commons Attribution License, which permits unrestricted use, distribution, and reproduction in any medium, provided the original work is properly cited.

\begin{abstract}
The association between diabetes mellitus (DM) and high mortality linked to cardiovascular disease (CVD) is a major concern worldwide. Clinical and preclinical studies have demonstrated a variety of diastolic and systolic dysfunctions in patients with type 2 diabetes mellitus (T2DM) with the severity of abnormalities depending on the patients' age and duration of diabetes. The cellular basis of hemodynamic dysfunction in a type 2 diabetic heart is still not well understood. The aim of this review is to evaluate our current understanding of contractile dysfunction and disturbances of $\mathrm{Ca}^{2+}$ transport in the Goto-Kakizaki (GK) diabetic rat heart. The GK rat is a widely used nonobese, nonhypertensive genetic model of T2DM which is characterized by insulin resistance, elevated blood glucose, alterations in blood lipid profile, and cardiac dysfunction.
\end{abstract}

\section{Use of the Goto-Kakizaki Diabetic Rat}

Diabetes mellitus (DM) is a metabolic disease characterized by abnormal glucose homeostasis and defects in insulin metabolism. Cardiovascular disease (CVD) is the leading cause of death in the diabetic population. However, the molecular mechanisms underlying diabetic cardiomyopathy remain unclear.

Animal models are increasingly being used to elucidate the mechanisms underlying diabetic cardiomyopathy in both type 1 and type 2 diabetes. One of the most widely used animal models of type 2 diabetes mellitus (T2DM) is the Goto-Kakizaki (GK) rat. The GK rat is a polygenic nonobese model of T2DM. This model is generated by selective inbreeding of mildly glucose-intolerant Wistar rats over many generations [1]. At least 17 genes associated with metabolism, signal transduction, receptors, and secreted factors are involved in the pathogenesis of diabetes in the GK rat [2]. The general characteristics of the GK rat include fasting hyperglycemia, impaired insulin secretion in response to glucose both in vivo and in isolated pancreata, raised glycosylated hemoglobin, hepatic and peripheral insulin resistance, altered heart and body weight, and a variety of late complications, including cardiomyopathy, nephropathy, and neuropathy [1,3-11]. In contrast to many other non-insulin-dependent rodent models, GK rats are non-obese $[1,12]$.

Three genetic loci are responsible for coding and transferring diabetic pathology to the fetus, and these include genes that are responsible for a reduction in $\beta$-cell mass and reduced insulin secretion [12]. During the prediabetic period (first three weeks after birth), animals have reduced body weight and do not show hyperglycemia. After weaning, many changes occur which include hyperglycemia, impaired glucose-induced insulin secretion (due to defective prenatal $\beta$-cell proliferation and reduction in $\beta$-cell mass), reduced insulin sensitivity in the liver, and moderate insulin resistance in peripheral tissues $[12,13]$. 
Persistent hyperglycemia over time provokes pancreatic islet inflammation, oxidative stress, fibrosis, and finally $\beta$-cell dysfunction. In fact, the pancreatic islets of adult GK rats show decreased $\beta$-cell number and insulin content as compared to their age-matched control animals [12].

GK rats have been considered as one of the best nonobese type 2 diabetic animal models. GK rats exhibit valuable characteristics that are more or less common and functionally present in human diabetic patients. This animal model is considered appropriate to examine various pathologic mechanisms of T2DM $[12,14]$. As mentioned earlier, reduced $\beta$-cell mass and reduced $\beta$-cell function are key characteristics found in this animal model [15]. Therefore, it is clear that GK rats form an important resource in preclinical T2DM research [16] in order to study the role of $\beta$-cell compensation in the pathogenesis of T2DM.

An earlier study has shown that GK islet fibrosis is accompanied by marked inflammation which is a characteristic that has been reported in islets of type 2 diabetic patients [17]. Other changes that are common between GK rats and human diabetic patients include decreased activity of glucose transporter (GLUT-2), glycerol-3-phosphate dehydrogenase $(\mathrm{GPDH})$, and glucokinase and changes in the lipid profile [12].

As in humans, GK rats also develop renal lesions, structural changes in peripheral nerves, and retinal damage [13]. For example, in adult GK rats, significant morphological alterations in kidneys occur in response to chronic hyperglycemia which are similar to that in human diabetic patients $[18,19]$. These morphological changes in kidneys include glomerulosclerosis, proliferation of mesangial cells, atrophy of basement membrane, and tubulointerstitial fibrosis [20].

\section{Other Animal Models of Type 2 Diabetes}

T2DM is characterized by insulin resistance and the inability of the $\beta$-cell to sufficiently compensate, which leads to hyperglycemia [21]. In addition, T2DM is closely associated with obesity which is one of the main pathological causes of insulin resistance [15, 22]. Many animal models are therefore obese as a result of naturally occurring mutations or genetic manipulation and are useful in understanding obesity-induced insulin resistance and its effects. These are divided into monogenic models, polygenic models, and diet-induced models [23]. The general characteristics for these obese models are insulin resistance and impaired glucose tolerance. In other words, these models lack sufficient insulin secretion required to compensate for the insulin resistance as part of the obesity (obesity-induced hyperglycemia) $[13,23]$.

Lep $^{\text {ob/ob }}$ mice, Lepr ${ }^{\mathrm{db} / \mathrm{db}}$ mice, and Zucker diabetic fatty rats are the most commonly used models of monogenic obesity. They have a disrupted leptin signaling pathway, leading to hyperphagia and obesity [13]. Polygenetic animal models, however, provide more accurate models of the human condition [15]. These include $\mathrm{KK}-\mathrm{A}^{\mathrm{Y}}$ mice, New Zealand obese (NZO) mice, TallHo/Jng mice, and Otsuka Long Evans Tokushima Fat (OLETF) rat. Obesity can also be induced by feeding the rodent a high-fat diet (diet- induced models). The weight gain in these animals is associated with insulin resistance and abnormal glucose metabolism [12, 13, 23].

In contrast to the animal models mentioned above, the GK rat is a non-obese animal model of T2DM. It is characterized by reduced $\beta$-cell mass and/or $\beta$-cell function [24]. The GK rat is glucose intolerant and displays defective glucoseinduced insulin secretion. Furthermore, the development of insulin resistance does not seem to be the main initiator of hyperglycemia. Instead, the defective glucose metabolism is regarded to be due to reduced $\beta$-cell mass [25] and/or function [26]. Adult GK rats show a $60 \%$ decrease in their total pancreatic $\beta$-cell mass. Blood glucose is elevated only after the first 3-4 weeks of animal's age, and blood glucose rises significantly after a glucose challenge $[13,27]$. The GK model is characterized by early hyperglycemia, hyperinsulinemia, and insulin resistance, $[1,12]$. Other examples of non-obese animal models of T2DM are the C57BL/6 (Akita) mutant mouse, the Cohen diabetic rats, and the spontaneously diabetic Torri (SDT) rats [13].

\section{Blood Chemistry in the Goto-Kakizaki Diabetic Rat}

Blood insulin, glucose, and lipid profiles in the GK rats compared to controls are summarized in Tables 1, 2, and 3, respectively. Blood insulin is either unaltered [28-34] or increased $[29,34,35]$ in the GK rats (Table 1). Fasting blood glucose and nonfasting blood glucose are slightly increased $[10,11,28-48]$ and urine glucose is increased [30] in the GK rat. Following a glucose challenge, in the fasted state, blood glucose is significantly elevated at 30, 60, and $120 \min [29,37-40,44,46,48-50]$ in the GK rat indicating end organ resistance to the action of insulin (Table 2). Blood cholesterol is increased [29, 35, 43,44] whilst high-density lipoprotein cholesterol may be either unaltered [31] or increased [44] and low-density lipoprotein cholesterol is unaltered $[31,44]$ in the GK rat compared to controls. Blood free fatty acids are either unaltered $[11,31]$ or increased $[38,45]$ in the GK rats compared to controls. Triglycerides are either increased [38, 43-45] or unaltered $[2,30,45]$ in the GK rats compared to controls (Table 3). Part of the variability in blood chemistry may be attributed to the age of the animals and dietary regime. In summary, the GK rat displays hyperglycemia, insulin resistance, and disturbances in lipid profile.

\section{Body and Heart Weight in the Goto-Kakizaki Diabetic Rat}

Body weight and heart weight measures in GK rats compared to controls are summarized in Tables 4 and 5, respectively. Body weight is either unaltered $[31,34,36,39-41,46,50]$, decreased [2, 10, 11, 28-30, 32, 35, 38, 42-46], or increased $[34,47,48]$ in the GK rat (Table 4 ). Heart weight is generally increased [29, 40, 41, 48, 49] but may also be decreased $[10,43]$ or unaltered $[11,39]$; left ventricular weight is either decreased [43, 45] or increased [32]; left ventricular thickness is increased [40] or unaltered [36]; right 
TABLE 1: Blood insulin in the GK rat.

\begin{tabular}{|c|c|c|c|}
\hline Parameter & Age & Control versus GK & Reference \\
\hline \multirow{11}{*}{ INS } & 5,15 , and $22 \mathrm{w}$ & 79.2 versus 77.4 [5], 151.4 versus $165.2^{*}[15]$, and 171.5 versus $234.1^{*}[22](\mathrm{pmol} / \mathrm{l})$ & {$[34]$} \\
\hline & 7,11 , and $15 \mathrm{w}$ & Increased at $7^{*}$ and $11 \mathrm{w}^{*}$, unaltered at $15 \mathrm{w}$ & [29] \\
\hline & $14-16 \mathrm{w}$ & 150 versus $176 \mathrm{pmol} / \mathrm{l} \mathrm{NSD}$ & {$[28]$} \\
\hline & $16 \mathrm{w}$ & 1.60 versus $2.11^{*}(\mu \mathrm{g} / \mathrm{ml})$ & {$[35]$} \\
\hline & $16 \mathrm{w}$ & 6.3 versus $5.3 \mathrm{mU} / \mathrm{l} \mathrm{NSD}$ & {$[30]$} \\
\hline & $18 \mathrm{w}$ & 4.9 versus $2.1 \mathrm{ng} / \mathrm{ml} \mathrm{NSD}$ & {$[31]$} \\
\hline & $20 \mathrm{w}$ & 4.1 versus $2.6 \mathrm{ng} / \mathrm{ml} \mathrm{NSD}$ & {$[32]$} \\
\hline & $20 \mathrm{w}$ & 1.7 versus $2.2 \mathrm{pg} / \mathrm{ml}$ NSD & {$[33]$} \\
\hline & 5,15 , and $22 \mathrm{w}$ & 79.2 versus $77.4[5], 151.4$ versus $165.2[15]$, and 171.5 versus $234.1^{*}[22](\mathrm{pmol} / \mathrm{l})$ & {$[34]$} \\
\hline & $24 \mathrm{w}$ & 14.5 versus $12.32 \mu \mathrm{g} / \mathrm{ml} \mathrm{NSD}$ & {$[2]$} \\
\hline & 18 and $30 \mathrm{w}$ & 132 versus $87^{*}[18]$ and 240 versus $85^{*}[30](\mathrm{pmol} / \mathrm{ml})$ & {$[45]$} \\
\hline
\end{tabular}

INS: insulin; NSD: no significant difference. ${ }^{*}$ Significant difference.

ventricular weight is either unaltered [45] or decreased [45] in GK rats compared to controls. Heart-weight-tobody-weight ratio is increased $[10,11,29,30,32,33,36,40$, 50] but may also be unaltered [31, 41, 48]; heart-weightto-femur-length ratio is increased [44]; left-ventricle-tobody-weight ratio is increased [36, 43, 45, 51]; right-ventricle-to-body-weight ratio is unaltered [45]; biventricularweight-to-body-weight and biventricular-weight-to-tibiallength ratios are increased [28, 45] (Table 5). In summary, the various heart to body ratio measures and the structural changes observed in the heart of this nonobese, nonhypertensive animal model provide evidence for regional cardiac hypertrophy.

Earlier studies have reported that chronic mild hyperglycemia produces molecular and structural correlates of hypertrophic myopathy in GK rats [40]. Several mechanisms whereby hyperglycemia may induce left ventricle remodeling have been proposed. One of these mechanisms is the increased activity of profibrotic and prohypertrophic cytokine transforming growth factor- $\beta 1$ (TGF- $\beta 1$ ) in the ventricular tissue [52]. TGF- $\beta 1$ reproduces most of the hallmarks seen in structural remodeling. Specifically, TGF- $\beta 1$ induces expression levels of extracellular matrix (ECM) constituents by cardiac fibroblasts (i.e., fibrillar collagen, fibronectin, and proteoglycans), self-amplifies its own expression in both cardiac myocytes and fibroblast $[53,54]$, and stimulates the proliferation of fibroblasts and their phenotypic conversion to myofibroblasts [55, 56]. D'Souza et al. have shown that the increased activity of TGF- $\beta 1$ and phosphorylation of protein kinase B (PKB)/Akt and its downstream effectors mediate the hypertrophic effects of TGF- $\beta 1$ in the prediabetic GK left ventricle [36]. The hypertrophic events were also sustained in the aging GK myocardium [40]. Earlier studies have suggested that enhanced activity of myocardial $\mathrm{Na}^{+} / \mathrm{H}^{+}$ exchanger plays a role in the molecular mechanisms involved in cardiac hypertrophy. It is likely that the activation of the Akt pathway mediates the hypertrophic effect of myocardial $\mathrm{Na}^{+} / \mathrm{H}^{+}$exchanger in the GK rat model of T2DM [28]. Interestingly, several studies have shown that female rat hearts are more hypertrophied than male hearts $[10,32,57]$.

\section{In Vivo Hemodynamic Function in the Goto-Kakizaki Rat Heart}

In vivo hemodynamic function and related measures in GK rats compared to controls are summarized in Table 6. Heart rate is either unaltered $[28,30-33,37,45,58]$ or reduced $[2$, $34,46]$ in the GK rat. Systolic blood pressure is unaltered $[28,30,31,33,58]$ or increased $[32,34,37,58]$; whilst diastolic blood pressure is increased [30, 34], mean arterial pressure is unaltered [35], increased [37], or reduced [30] in GK rat. Rate for pressure development $(+\mathrm{dP} / \mathrm{dt})$ and decline $(-\mathrm{dP} / \mathrm{dt})$ in left ventricle is unaltered $[30,45]$ in the GK rat. Ejection fraction is reduced [28, 51], increased [44], or unaltered [30, 33]; fractional shortening is reduced $[32,51]$ or unaltered $[2,33$, 45]; cardiac output is unaltered [33] or decreased [51] in the GK rat. Coronary blood flow is increased [29] or reduced [2] in GK rats compared to controls. In summary, the GK rat heart may display a variety of abnormal hemodynamic characteristics including alterations in heart rate, blood pressure, blood pumping capability, and altered coronary blood flow.

\section{Hemodynamic Function in the Isolated Perfused Goto-Kakizaki Rat Heart}

Heart rate in the isolated perfused heart is lower in comparison to the heart rate in vivo in GK and control hearts (Table 7). Isolated perfused heart rate is unaltered $[10,11,31,50]$ in GK rats. Left ventricle $+\mathrm{dP} / \mathrm{dt}$ and $-\mathrm{dP} / \mathrm{dt}$ are either unaltered $[10,31,59]$ or reduced $[51]$ in the GK rat. Coronary flow is either reduced $[11,31]$ or unaltered [10] in GK rats compared to controls. Collectively, the GK rat heart displays a variety of abnormal hemodynamic characteristics, including altered rate of development and relaxation of ventricular contraction and altered coronary flow compared to controls. 
TABLE 2: Glucose profile in the GK rat.

\begin{tabular}{|c|c|c|c|}
\hline Parameter & Age & Control versus GK & Reference \\
\hline \multirow{9}{*}{ FBG } & $8 \mathrm{w}$ & 76.2 versus $107.0^{*}(\mathrm{mg} / \mathrm{dl})$ & {$[36]$} \\
\hline & 5,15 , and $22 \mathrm{w}$ & 6.14 versus $7.49^{*}[5], 7.56$ versus $8.71^{*}[15]$, and 5.26 versus $9.02^{*}[22](\mathrm{mmol} / \mathrm{l})$ & {$[34]$} \\
\hline & 7,11 , and $15 \mathrm{w}$ & Increased at $7^{*}, 11^{*}$, and $15^{*}(\mathrm{w})$ & [29] \\
\hline & $16 \mathrm{w}$ & 4.8 versus $8.8^{*}(\mathrm{mmol} / \mathrm{l})$ & [35] \\
\hline & $26 \mathrm{w}$ & Increased* & [37] \\
\hline & $26 \mathrm{w}$ & 65.8 versus $99.1^{*}(\mathrm{mg} / \mathrm{dl})$ & [38] \\
\hline & $17 \mathrm{~m}$ & 72.1 versus $151.5^{*}(\mathrm{mg} / \mathrm{dl})$ & [39] \\
\hline & $18 \mathrm{~m}$ & 95.2 versus $131.4^{*}(\mathrm{mg} / \mathrm{dl})$ & {$[40]$} \\
\hline & $18 \mathrm{~m}$ & 44 versus $51 \mathrm{mg} / \mathrm{dl}$ NSD & {$[50]$} \\
\hline \multirow{17}{*}{ NFBG } & $8-10 w$ & 118.40 versus $166.40^{*}(\mathrm{mg} / \mathrm{dl})$ & {$[41]$} \\
\hline & $11 \mathrm{w}$ & 7.40 versus $9.18^{*}(\mathrm{mM})$ & {$[42]$} \\
\hline & $12 \mathrm{w}$ & 9.02 versus $26.57^{*}(\mathrm{mmol} / \mathrm{l})$ & {$[43]$} \\
\hline & $14-16 \mathrm{w}$ & 9.4 versus $14.3^{*}(\mathrm{mmol} / \mathrm{l})$ & {$[28]$} \\
\hline & $16 \mathrm{w}$ & 8.5 versus $12.8^{*}(\mathrm{mmol} / \mathrm{l})$ & {$[30]$} \\
\hline & $18 \mathrm{w}$ & 6.0 versus $12.7^{*}(\mathrm{mM})$ & {$[31]$} \\
\hline & $20 \mathrm{w}$ & 7.5 versus $17.9^{*}(\mathrm{mmol} / \mathrm{l})$ & {$[32]$} \\
\hline & $20 \mathrm{w}$ & 4.9 versus $8.2^{*}(\mathrm{mmol} / \mathrm{l})$ & [33] \\
\hline & 5,15 , and $22 \mathrm{w}$ & 6.14 versus $7.49^{*}[5], 7.56$ versus $8.71^{*}[15]$, and 5.26 versus $9.02^{*}[22](\mathrm{mmol} / \mathrm{l})$ & [34] \\
\hline & $26 \mathrm{w}$ & 204.42 versus $531.71^{*}(\mathrm{mg} / \mathrm{dl})$ & {$[44]$} \\
\hline & 18 and $30 \mathrm{w}$ & 18.7 versus $24.9^{*}[18]$ and 19.2 versus $27.6^{*}[30](\mu \mathrm{mol} / \mathrm{ml})$ & [45] \\
\hline & 3,6 , and $15 \mathrm{~m}$ & 49.6 versus $48.4[3], 48.1$ versus $73.3^{*}[6]$, and 68.6 versus $113.3^{*}[15](\mathrm{mg} / \mathrm{dl})$ & [46] \\
\hline & $5-8 \mathrm{~m}$ & 11.3 versus $14.7^{*}(\mathrm{mmol} / \mathrm{l})$ & {$[10]$} \\
\hline & $9-14 \mathrm{~m}$ & 10.3 versus $17.0^{*}(\mathrm{mM})$ & [11] \\
\hline & $10 \mathrm{~m}$ & 95.77 versus $143.06^{*}(\mathrm{mg} / \mathrm{dl})$ & [47] \\
\hline & $10-11 \mathrm{~m}$ & 91.67 versus $161.29^{*}(\mathrm{mg} / \mathrm{dl})$ & {$[48]$} \\
\hline & $17 \mathrm{~m}$ & 101.4 versus $188.8^{*}(\mathrm{mg} / \mathrm{dl})$ & {$[39]$} \\
\hline UG & $16 \mathrm{w}$ & 0.13 versus $0.73^{*}(\mathrm{~g} / \mathrm{l})$ & {$[30]$} \\
\hline \multirow{10}{*}{ OGTT } & $8 \mathrm{w}$ & Elevated at $30^{*}, 60^{*}$, and $120^{*}(\mathrm{~min})$ & [36] \\
\hline & $15 \mathrm{w}$ & Elevated at $30^{*}, 60^{*}$, and $120^{*}(\mathrm{~min})$ & {$[29]$} \\
\hline & $16 \mathrm{w}$ & Elevated at $30^{*}$ and $60^{*}(\mathrm{~min})$ & [37] \\
\hline & $26 \mathrm{w}$ & Elevated at $15^{*}$ and $60^{*}(\mathrm{~min})$ & {$[44]$} \\
\hline & $26 \mathrm{w}$ & 83.2 versus $303.4^{*}(\mathrm{mg} / \mathrm{dl})$ at $120 \mathrm{~min}$ & {$[38]$} \\
\hline & $10-11 \mathrm{~m}$ & 93.93 versus $236.27^{*}(\mathrm{mg} / \mathrm{dl})$ at $120 \mathrm{~min}$ & {$[48]$} \\
\hline & $15 \mathrm{~m}$ & 183.3 versus $276.9^{*}(\mathrm{mg} / \mathrm{dl})$ at $120 \mathrm{~min}$ & {$[46]$} \\
\hline & $17 \mathrm{~m}$ & 148.1 versus $570.8^{*}(\mathrm{mg} / \mathrm{dl})$ at $120 \mathrm{~min}$ & [39] \\
\hline & $18 \mathrm{~m}$ & Elevated at $30^{*}, 60^{*}, 120^{*}$, and $180^{*}(\mathrm{~min})$ & {$[40]$} \\
\hline & $18 \mathrm{~m}$ & 153.4 versus $436.3^{*}(\mathrm{mg} / \mathrm{dl})$ at $180 \mathrm{~min}$ & {$[50]$} \\
\hline OGTT & $15 \mathrm{w}$ & Increased $^{*}$ area under curve & {$[29]$} \\
\hline \multirow{2}{*}{ HbAlc } & $25 \mathrm{w}$ & 3.5 versus $5.4^{*}(\%)$ & [38] \\
\hline & $5-8 \mathrm{~m}$ & 4.0 versus $4.8^{*}(\%)$ & {$[10]$} \\
\hline HOMA-IR & 7,11 , and $15 \mathrm{w}$ & Increased at $7^{*}, 11^{*}$, and NSD $15(\mathrm{w})$ & [29] \\
\hline
\end{tabular}

FBG: fasting blood glucose; NFBG: nonfasting blood glucose; UG: urine glucose; OGTT: oral glucose tolerance test; HbAlc: glycated hemoglobin Alc; HOMA-IR: homeostasis model assessment-estimated insulin resistance; NSD: no significant difference. *Significant difference.

\section{Contraction in Ventricular Myocytes from the Goto-Kakizaki Rat Heart}

Characteristics of shortening in myocytes from GK rats compared to controls are shown in Table 8. Myocyte diameter, surface area, cross-sectional area, and cell capacitance were increased [28, 30, 33, 36, 40, 51], and resting cell length may be unaltered $[10,39,41,50]$ or increased [47] in myocytes from the GK rat. In electrically stimulated myocytes, the time-to-peak (TPK) shortening was prolonged 
TABLE 3: Lipid profile in the GK rat.

\begin{tabular}{|c|c|c|c|}
\hline Parameter & Age & Control versus GK & Reference \\
\hline \multirow{5}{*}{$\mathrm{CHOL}$} & 7,11 , and $15 \mathrm{w}$ & Increased at $7^{*}, 11^{*}$, and $15^{*}$ (weeks) & {$[29]$} \\
\hline & $12 \mathrm{w}$ & 1.34 versus $2.15^{*}(\mathrm{mmol} / \mathrm{l})$ & [43] \\
\hline & $16 \mathrm{w}$ & 1.71 versus $1.98^{*}(\mathrm{mmol} / \mathrm{l})$ & [35] \\
\hline & $16 \mathrm{w}$ & 70 versus 93 mg/dl NSD & {$[30]$} \\
\hline & $26 \mathrm{w}$ & 55.57 versus $93.0^{*}(\mathrm{mg} / \mathrm{dl})$ & {$[44]$} \\
\hline \multirow{2}{*}{ HDL CHOL } & $18 \mathrm{w}$ & 26.9 versus $29.1 \mathrm{mg} / \mathrm{ml} \mathrm{NSD}$ & {$[31]$} \\
\hline & $26 \mathrm{w}$ & 22.0 versus $41.85^{*}(\mathrm{mg} / \mathrm{dl})$ & {$[44]$} \\
\hline \multirow{2}{*}{ LDL CHOL } & $18 \mathrm{w}$ & 35.4 versus $39.5 \mathrm{mg} / \mathrm{ml}$ & {$[31]$} \\
\hline & $26 \mathrm{w}$ & 20.42 versus $25.34 \mathrm{mg} / \mathrm{dl}$ & {$[44]$} \\
\hline \multirow{4}{*}{ FFA } & $18 \mathrm{w}$ & 0.61 versus $0.54 \mathrm{mM}$ NSD & [31] \\
\hline & 18 and $30 \mathrm{w}$ & 0.30 versus $0.60^{*}[18]$ and 0.41 versus $0.53^{*}[30](\mu \mathrm{mol} / \mathrm{ml})$ & [45] \\
\hline & $26 \mathrm{w}$ & 0.55 versus $1.3^{*}(\mathrm{mM})$ & [38] \\
\hline & $9-14 \mathrm{~m}$ & 0.2 versus $0.3 \mathrm{mM}$ NSD & [11] \\
\hline \multirow{7}{*}{ TG } & $12 \mathrm{w}$ & 0.54 versus $1.21^{*}(\mathrm{mmol} / \mathrm{l})$ & [43] \\
\hline & $16 \mathrm{w}$ & 1.72 versus $0.85^{*}(\mathrm{mmol} / \mathrm{l})$ & {$[35]$} \\
\hline & $16 \mathrm{w}$ & 67 versus $60 \mathrm{mg} / \mathrm{dl} \mathrm{NSD}$ & [30] \\
\hline & $24 \mathrm{w}$ & 877.01 versus $1219.97 \mu \mathrm{mol} / \mathrm{l} \mathrm{NSD}$ & {$[2]$} \\
\hline & $26 \mathrm{w}$ & 98.2 versus $134.9^{*}(\mathrm{mg} / \mathrm{dl})$ & [38] \\
\hline & $26 \mathrm{w}$ & 65.14 versus $129.42^{*}(\mathrm{mg} / \mathrm{dl})$ & {$[44]$} \\
\hline & 18 and $30 \mathrm{w}$ & 0.74 versus $0.91[18]$ and 0.93 versus $1.35^{*}[30](\mathrm{mg} / \mathrm{ml})$ & {$[45]$} \\
\hline
\end{tabular}

CHOL: cholesterol; HDL: high-density lipoproteins; LDL: low-density lipoproteins; FFA: free fatty acids; TG: Triglycerides; NSD: no significant difference. *Significant difference.

$[39,41,47]$ or unaltered $[48,50]$ and the time-tohalf (THALF) relaxation of shortening may be unaltered $[41,47,48]$ or shortened [50] or lengthened [39] in myocytes from the GK rat. Amplitude of shortening may be unaltered $[10,41,48,50]$ or increased [39] in myocytes from the GK rat. In summary, ventricular myocytes from the GK rat heart tend to be larger in size and have prolonged time course and generally similar amplitude of contraction compared to myocytes from the control heart.

During the process of excitation-contraction coupling (ECC), the arrival of an action potential causes depolarization of the cardiac myocyte plasma membrane. This depolarization opens voltage-gated L-type $\mathrm{Ca}^{2+}$ channels in the plasma membrane. The entry of small amounts of $\mathrm{Ca}^{2+}$ through these channels triggers a large release of $\mathrm{Ca}^{2+}$ from the sarcoplasmic reticulum (SR) via activation of the ryanodine receptor (RyR), by the process termed calciuminduced calcium release (CICR). The transient rise in intracellular $\mathrm{Ca}^{2+}\left(\mathrm{Ca}^{2+}\right.$ transient $)$ results in the binding of $\mathrm{Ca}^{2+}$ to troponin $\mathrm{C}$ which initiates and regulates the process of cardiac muscle cell contraction. During the process of relaxation, $\mathrm{Ca}^{2+}$ is pumped back into the $\mathrm{SR}$ via the $\mathrm{SR}$ $\mathrm{Ca}^{2+}$-ATPase (SERCA2) and extruded from the cell, primarily via the $\mathrm{Na}^{+} / \mathrm{Ca}^{2+}$ exchanger (NCX) [60, 61]. Changes in the kinetics of shortening observed in myocytes of GK rats may be attributed, at least in part, to alternations in ventricular myocardial stiffness. Earlier studies have demonstrated increased collagen deposition and increased ventricular stiffness in different experimental models of T2DM, which in turn were associated with altered kinetics of myocardial contraction [62, 63]. The observed disturbance in myocyte shortening may also be attributed to the alternation in the profile of expression of mRNA encoding various proteins involved in excitationcontraction coupling [48].

\section{Intracellular $\mathrm{Ca}^{2+}$ in Ventricular Myocytes from the Goto-Kakizaki Rat Heart}

Characteristics of intracellular $\mathrm{Ca}^{2+}$ in myocytes from GK rats compared to controls are shown in Table 9. Resting intracellular $\mathrm{Ca}^{2+}$ is unaltered $[10,41,47,48]$ or increased [28]; TPK Ca ${ }^{2+}$ transient is unaltered $[39,41,48,50]$ or prolonged [47]; THALF decay of the $\mathrm{Ca}^{2+}$ transient is unaltered $[39,47,48,50]$ or shortened [41]; and the amplitude of the $\mathrm{Ca}^{2+}$ transient is unaltered $[10,41,48]$, increased $[47,50]$, or decreased [39] in myocytes from the GK rat. In wholecell patch clamp experiments, the amplitude, inactivation, and restitution of L-type $\mathrm{Ca}^{2+}$ current are unaltered [48] in myocytes from GK rats compared to controls.

Since intracellular $\mathrm{Ca}^{2+}$ in cardiac cells is maintained by $\mathrm{Ca}^{2+}$ influx (through L-type $\mathrm{Ca}^{2+}$ channels; the primary trigger for $\mathrm{SR} \mathrm{Ca}^{2+}$ release) and efflux (through NCX; the major pathway for $\mathrm{Ca}^{2+}$ efflux from the cell) [64], as well as $\mathrm{Ca}^{2+}$ release (via the ryanodine receptors) and uptake by both SR (through SERCA2) and mitochondria, it is possible that the observed differences in these results may be attributed to differential changes in $\mathrm{Ca}^{2+}$ transport activities in these organelles. Furthermore, the observed alterations in 
TABLE 4: Body weight of the GK rat.

\begin{tabular}{|c|c|c|c|}
\hline Parameter & Age & Control versus GK & Reference \\
\hline \multirow{24}{*}{ BW } & 5,15 , and $22 \mathrm{w}$ & 82.0 versus $106.9^{*}$ [5], 311.8 versus $315.0^{*}[15]$, and 464.3 versus $417.8^{*}$ [22] (g) & {$[34]$} \\
\hline & $8 \mathrm{w}$ & 325.25 versus $329.00 \mathrm{~g}$ NSD & [36] \\
\hline & $8-10 \mathrm{w}$ & 218.50 versus $246.40 \mathrm{~g}$ NSD & [41] \\
\hline & $11 \mathrm{w}$ & 402 versus $275^{*}(\mathrm{~g})$ & {$[42]$} \\
\hline & $12 \mathrm{w}$ & 432 versus $353^{*}(\mathrm{~g})$ & [43] \\
\hline & $15 \mathrm{w}$ & Reduced* & [29] \\
\hline & $14-16 \mathrm{w}$ & 376 versus $330^{*}(\mathrm{~g})$ & [28] \\
\hline & $16 \mathrm{w}$ & 481.3 versus $414.0^{*}(\mathrm{~g})$ & [35] \\
\hline & $16 \mathrm{w}$ & 450 versus $331^{*}(\mathrm{~g})$ & {$[30]$} \\
\hline & $18 \mathrm{w}$ & 376 versus 372 g NSD & {$[31]$} \\
\hline & $20 \mathrm{w}$ & 437 versus $385^{*}(\mathrm{~g})$ & [32] \\
\hline & 5,15 , and $22 \mathrm{w}$ & 82 versus $106.9^{*}[5], 311.8$ versus 315 [15], and 464.3 versus 417.8 [22] (g) & {$[34]$} \\
\hline & $24 \mathrm{w}$ & 491.67 versus $334.17^{*}(\mathrm{~g})$ & {$[2]$} \\
\hline & $26 \mathrm{w}$ & 453.8 versus $401.7^{*}(\mathrm{~g})$ & {$[44]$} \\
\hline & $26 \mathrm{w}$ & 402.3 versus $351.4^{*}(\mathrm{~g})$ & [38] \\
\hline & 18 and $30 \mathrm{w}$ & 501 versus $386^{*}[18]$ and 643 versus $427^{*}[30](\mathrm{g})$ & {$[45]$} \\
\hline & 2,7 , and $10 \mathrm{~m}$ & 205.7 versus 230.3 [2], 469.9 versus $417.5^{*}[7]$, and 494.0 versus $406.3^{*}[10](\mathrm{g})$ & {$[46]$} \\
\hline & $5-8 \mathrm{~m}$ & 559.5 versus $379.6^{*}(\mathrm{~g})$ & {$[10]$} \\
\hline & $9-14 \mathrm{~m}$ & 628 versus $396^{*}(\mathrm{~g})$ & [11] \\
\hline & $10 \mathrm{~m}$ & 383.31 versus $442.38^{*}(\mathrm{~g})$ & [47] \\
\hline & $10-11 \mathrm{~m}$ & 400.3 versus $443.64^{*}(\mathrm{~g})$ & {$[48]$} \\
\hline & $17 \mathrm{~m}$ & 436 versus 399 g NSD & [39] \\
\hline & $18 \mathrm{~m}$ & 418.7 versus $413.4 \mathrm{~g}$ NSD & {$[40]$} \\
\hline & $18 \mathrm{~m}$ & 513.4 versus $457.9 \mathrm{~g}$ NSD & {$[50]$} \\
\hline
\end{tabular}

BW: body weight; NSD: no significant difference. * Significant difference.

intracellular $\mathrm{Ca}^{2+}$ may also be due to differences in the stage and severity of diabetes $[65,66]$.

It is well known that alterations in $\mathrm{SR} \mathrm{Ca}^{2+}$ uptake and release mechanisms would impair cardiac cell function. Several studies have reported changes in cardiac SR $\mathrm{Ca}^{2+}$ transport during the development of chronic diabetes [67-71]. For example, Ganguly et al. reported that a decrease in $\mathrm{Ca}^{2+}$ uptake activity by SR was associated with a decrease in SERCA2a activity [68]. Furthermore, Golfman et al. showed that SR ATP-dependent $\mathrm{Ca}^{2+}$ uptake activity was markedly decreased in the diabetic rat heart [72]. Yu et al. reported a reduction in both SR $\mathrm{Ca}^{2+}$ content and ryanodine binding sites in diabetic hearts, indicating that the SR functions of storage and release of $\mathrm{Ca}^{2+}$ were depressed [73]. It should be noted that prolonged depression of the SR $\mathrm{Ca}^{2+}$ uptake activity in chronic diabetes may contribute to the occurrence of intracellular $\mathrm{Ca}^{2+}$ overload [65].

In our recently published data, L-type $\mathrm{Ca}^{2+}$ current and $\mathrm{Ca}^{2+}$ transients were simultaneously measured in endocardial (ENDO) and epicardial (EPI) myocytes from the left ventricle of GK rats [74]. Consistent with previous findings [48], the amplitude of L-type $\mathrm{Ca}^{2+}$ current, over a wide range of test potentials, was unaltered in ENDO and EPI myocytes from the left ventricle of GK rat. However, the amplitude of the $\mathrm{Ca}^{2+}$ transients was reduced and by similar extents, in
ENDO and EPI myocytes from the GK rat heart. The THALF decay of the $\mathrm{Ca}^{2+}$ transients was reduced in EPI and ENDO myocytes from GK rats compared to controls. Interestingly, while a reduction in the amplitude of L-type $\mathrm{Ca}^{+}$current has been reported in earlier studies on a diabetic heart $[75,76]$, it does not necessarily explain the reduced $\mathrm{Ca}^{2+}$ transients. This is because many reports show no change in L-type $\mathrm{Ca}^{2+}$ current despite the reduction in both contractions and $\mathrm{Ca}^{2+}$ transients [48, 74, 77-79]. Instead, reduction of $\mathrm{Ca}^{2+}$ transients and the consequent contractile dysfunction may be due to depletion of SR $\mathrm{Ca}^{2+}$, which may result from RYR-dependent $\mathrm{Ca}^{2+}$ leak, an increased $\mathrm{Ca}^{2+}$ extrusion through NCX, or a reduced function of SERCA [61, 80]. Further experiments will be required to investigate the role of SR in $\mathrm{Ca}^{2+}$ transport in myocytes from the GK rat. Sheikh et al. [81] demonstrated that cardiac endothelial cells from diabetic rats treated with NCX inhibitor have higher intracellular $\mathrm{Ca}^{2+}$ transient peaks as compared to controls. This finding supports the idea that altered activity of sarcolemmal NCX during $\mathrm{Ca}^{2+}$ efflux contributes to the decrease in $\mathrm{Ca}^{2+}$ transient-observed GK myocytes. Previous experiments in ventricular myocytes from the streptozotocininduced diabetic rats have reported reduced caffeine-evoked $\mathrm{Ca}^{2+}$ transients [82-91], SERCA2 activity, and $\mathrm{Ca}^{2+}$ uptake $[83,88,92-94]$ and decreased SR $\mathrm{Ca}^{2+}$ channel (ryanodine 
TABLE 5: Heart weight and other heart-related measurements in the GK rat.

\begin{tabular}{|c|c|c|c|}
\hline Parameter & Age & Control versus GK & Reference \\
\hline \multirow{9}{*}{ HW } & $8 w$ & 0.807 versus $0.927^{*}(\mathrm{~g})$ & {$[36]$} \\
\hline & $8-10 w$ & 0.96 versus $1.05^{*}(\mathrm{~g})$ & [41] \\
\hline & $12 \mathrm{w}$ & 1.14 versus $0.98^{*}(\mathrm{~g})$ & [43] \\
\hline & $15 \mathrm{w}$ & Increased $^{*}$ & {$[29]$} \\
\hline & $5-8 \mathrm{~m}$ & 1700 versus $1460^{*}(\mathrm{mg})$ & {$[10]$} \\
\hline & $9-14 \mathrm{~m}$ & 2.0 versus $1.8 \mathrm{~g} \mathrm{NSD}$ & {$[11]$} \\
\hline & $10-11 \mathrm{~m}$ & 1.37 versus $1.60^{*}(\mathrm{~g})$ & {$[48]$} \\
\hline & $17 \mathrm{~m}$ & 1.52 versus $1.50 \mathrm{~g}$ NSD & {$[39]$} \\
\hline & $18 \mathrm{~m}$ & 1.22 versus $1.41^{*}(\mathrm{~g})$ & {$[40]$} \\
\hline \multirow{3}{*}{ LVW } & $12 \mathrm{w}$ & 0.81 versus $0.68^{*}(\mathrm{~g})$ & [43] \\
\hline & 18 and $30 \mathrm{w}$ & 1.12 versus $0.86^{*}[18]$ and 1.32 versus $1.03^{*}[30](\mathrm{g})$ & {$[45]$} \\
\hline & $20 \mathrm{w}$ & Increased $^{*}$ & {$[32]$} \\
\hline \multirow{2}{*}{ LVT } & $8 \mathrm{w}$ & 2.98 versus $3.15 \mathrm{~mm}$ NSD & {$[36]$} \\
\hline & $18 \mathrm{~m}$ & 3.08 versus $3.35^{*}(\mathrm{~mm})$ & {$[40]$} \\
\hline RVW & 18 and $30 \mathrm{w}$ & 0.30 versus $0.26[18]$ and 0.32 versus $0.28^{*}[30](\mathrm{g})$ & {$[45]$} \\
\hline \multirow{12}{*}{$\mathrm{HW} / \mathrm{BW}$} & 8 weeks & 0.248 versus $0.281^{*}(\mathrm{~g} / 100 \mathrm{~g})$ & {$[36]$} \\
\hline & $8-10 \mathrm{w}$ & 4.43 versus $4.33 \mathrm{mg} / \mathrm{g}$ NSD & {$[41]$} \\
\hline & $15 \mathrm{w}$ & Increased ${ }^{*}$ & {$[29]$} \\
\hline & $16 \mathrm{w}$ & 2.96 versus $3.73^{*}$ & {$[30]$} \\
\hline & $18 \mathrm{w}$ & 2.2 versus $2.2 \mathrm{NSD}$ & {$[31]$} \\
\hline & $20 \mathrm{w}$ & Increased ${ }^{*}$ & {$[32]$} \\
\hline & $20 \mathrm{w}$ & Increased* & {$[33]$} \\
\hline & $9-14 \mathrm{~m}$ & 3.1 versus $4.5^{*}$ & {$[11]$} \\
\hline & $5-8 \mathrm{~m}$ & 3.0 versus $3.8^{*}(\mathrm{mg} / \mathrm{g})$ & {$[10]$} \\
\hline & $10-11 \mathrm{~m}$ & 3.43 versus $3.61 \mathrm{mg} / \mathrm{g}$ NSD & {$[48]$} \\
\hline & $18 \mathrm{~m}$ & 0.21 versus $0.34^{*}(\mathrm{~g} / 100 \mathrm{~g})$ & {$[40]$} \\
\hline & $18 \mathrm{~m}$ & 3.36 versus $4.10^{*}(\mathrm{mg} / \mathrm{g})$ & {$[50]$} \\
\hline $\mathrm{HW} / \mathrm{FL}$ & $26 \mathrm{w}$ & 0.44 versus $0.49^{*}$ & {$[44]$} \\
\hline \multirow{4}{*}{$\mathrm{LV} / \mathrm{BW}$} & $8 \mathrm{w}$ & 1.76 versus $1.98^{*}(\mathrm{mg} / \mathrm{g})$ & {$[36]$} \\
\hline & $12 \mathrm{w}$ & 1.85 versus $1.95^{*}(\mathrm{mg} / \mathrm{g})$ & [43] \\
\hline & 18 and $30 \mathrm{w}$ & 2.16 versus $2.24^{*}[18]$ and 2.06 versus $2.40^{*}[30](\mathrm{mg} / \mathrm{kg})$ & {$[45]$} \\
\hline & $6 \mathrm{~m}$ & 0.20 versus $0.24^{*}(\%)$ & {$[51]$} \\
\hline $\mathrm{RV} / \mathrm{BW}$ & 18 and $30(\mathrm{w})$ & 0.60 versus $0.71[18]$ and 0.50 versus $0.66[30](\mathrm{mg} / \mathrm{g})$ & {$[45]$} \\
\hline \multirow{2}{*}{$\mathrm{BVW} / \mathrm{BW}$} & $14-16 \mathrm{w}$ & Increased $^{*}$ & {$[28]$} \\
\hline & 18 and $30 \mathrm{w}$ & 2.76 versus $2.94^{*}[18]$ and 2.56 versus $3.06^{*}[30](\mathrm{mg} / \mathrm{g})$ & {$[45]$} \\
\hline $\mathrm{BVW} / \mathrm{TL}$ & $14-16 \mathrm{w}$ & Increased $^{*}$ & {$[28]$} \\
\hline
\end{tabular}

HW: heart weight; LVM: left ventricular weight; LVT: left ventricular thickness; RVW: right ventricular weight; BW: body weight; FL: femur length; BVW: biventricular weight; TL: tibial length; NSD: no significant difference. ${ }^{*}$ Significant difference.

receptor) activity $[87,95]$ suggesting decreased $\mathrm{SR} \mathrm{Ca}^{2+}$ content, $\mathrm{Ca}^{2+}$ uptake, and $\mathrm{Ca}^{2+}$ release mechanisms in ventricular myocytes from the streptozotocin-induced diabetic rat.

Under pathological conditions, such as chronic diabetes, the mitochondria are able to accumulate large amounts of $\mathrm{Ca}^{2+}$, which serves as a protective mechanism during cardiac dysfunction and intracellular $\mathrm{Ca}^{2+}$ overload. Therefore, altered mitochondrial uptake of $\mathrm{Ca}^{2+}$ during diabetes may contribute to the reported decreased $\mathrm{Ca}^{2+}$ transients. Although the mitochondria contribute to $\mathrm{Ca}^{2+}$ signaling, their exact role in diabetic cardiomyopathy remains to be investigated.

Recent investigations, using animal models, suggest that mitochondrial dysfunction may also play a critical role in the pathogenesis of diabetic cardiomyopathy [65, 71]. Potential mechanisms that contribute to mitochondrial impairment in diabetes include altered energy metabolism [96-99] oxidative stress [100-102], altered mitochondrial dynamics and biogenesis $[103,104]$, cell death $[105,106]$, and impaired mitochondrial $\mathrm{Ca}^{2+}$ handling $[107,108]$. 
TABLE 6: In vivo hemodynamic function in the GK rat.

\begin{tabular}{|c|c|c|c|}
\hline Parameter & Age & Control versus GK & Reference \\
\hline \multirow{12}{*}{ HR } & 15 and $22 \mathrm{w}$ & 344.7 versus $314.1^{*}[15]$ and 333.1 versus $296.7^{*}[22](b p m)$ & {$[34]$} \\
\hline & $14-16 \mathrm{w}$ & 322 versus $328 \mathrm{bpm}$ NSD & {$[28]$} \\
\hline & $16 \mathrm{w}$ & NSD & {$[37]$} \\
\hline & $16 \mathrm{w}$ & 453 versus $454 \mathrm{bpm}$ NSD & {$[30]$} \\
\hline & $18 \mathrm{w}$ & 369 versus $417 \mathrm{bpm}$ NSD & {$[31]$} \\
\hline & $20 \mathrm{w}$ & 208 versus $217 \mathrm{bpm} \mathrm{NSD}$ & {$[32]$} \\
\hline & $20 \mathrm{w}$ & 341 versus $360 \mathrm{bpm}$ NSD & {$[33]$} \\
\hline & 15 and $22 \mathrm{w}$ & 344.7 versus $314.1^{*}[15]$ and 333.1 versus $296.7^{*}[22](\mathrm{bpm})$ & {$[34]$} \\
\hline & $24 \mathrm{w}$ & 370.33 versus $323.00^{*}(\mathrm{bpm})$ & {$[2]$} \\
\hline & 18 and $30 \mathrm{w}$ & 337 versus $350[18]$ and 319 versus $328 \mathrm{bpm}[30] \mathrm{NSD}$ & {$[45]$} \\
\hline & 2,7 , and $15 \mathrm{~m}$ & 370 versus $316^{*}[2], 324$ versus $264^{*}[7]$, and 307 versus $256^{*}[15](\mathrm{bpm})$ & {$[46]$} \\
\hline & $3 \mathrm{~m}$ & NSD & [58] \\
\hline \multirow{9}{*}{ SBP } & 15 and $22 \mathrm{w}$ & 122.3 versus $138.4^{*}[15]$ and 117.5 versus $135.0^{*}[22](\mathrm{mmHg})$ & {$[34]$} \\
\hline & $14-16 \mathrm{w}$ & 131 versus $134 \mathrm{mmHg}$ NSD & {$[28]$} \\
\hline & $16 \mathrm{w}$ & Higher* & {$[37]$} \\
\hline & $16 \mathrm{w}$ & 145 versus $123 \mathrm{mmHg}$ NSD & {$[30]$} \\
\hline & $18 \mathrm{w}$ & 117 versus $121 \mathrm{mmHg}$ NSD & [31] \\
\hline & $20 \mathrm{w}$ & Higher* & [32] \\
\hline & $20 \mathrm{w}$ & 144 versus $149 \mathrm{mmHg}$ NSD & {$[33]$} \\
\hline & 15 and $22 \mathrm{w}$ & 122.3 versus $138.4^{*}[15]$ and 117.5 versus $135.0^{*}[22](\mathrm{mmHg})$ & {$[34]$} \\
\hline & $3 \mathrm{~m}$ & 124 versus $152^{*}(\mathrm{mmHg})$ & {$[58]$} \\
\hline \multirow{3}{*}{ DBP } & 15 and $22 \mathrm{w}$ & 88.1 versus $95.4^{*}[15]$ and 84.0 versus $91.6[22](\mathrm{mmHg})$ & {$[34]$} \\
\hline & $16 \mathrm{w}$ & 117 versus $89^{*}(\mathrm{mmHg})$ & [30] \\
\hline & 15 and $22 \mathrm{w}$ & 88.1 versus $95.4^{*}[15]$ and 84.0 versus $91.6 \mathrm{mmHg}$ [22] & {$[34]$} \\
\hline \multirow{3}{*}{ MAP } & $16 \mathrm{w}$ & 117 versus $120 \mathrm{mmHg}$ NSD & {$[35]$} \\
\hline & $16 \mathrm{w}$ & Higher* & {$[37]$} \\
\hline & $16 \mathrm{w}$ & 126 versus $100^{*}(\mathrm{mmHg})$ & {$[30]$} \\
\hline PLVP & 18 and $30 \mathrm{w}$ & 106 versus $105[18]$ and 112 versus $108 \mathrm{mmHg}$ [30] NSD & {$[45]$} \\
\hline \multirow{2}{*}{$\mathrm{LV}+\mathrm{dP} / \mathrm{dt}$} & 18 and $30 \mathrm{w}$ & 6510 versus 5953 [18] and 6846 versus $5840 \mathrm{mmHg} / \mathrm{s}$ [30] NSD & [45] \\
\hline & $26 \mathrm{w}$ & NSD & {$[30]$} \\
\hline \multirow{2}{*}{$\mathrm{LV}-\mathrm{dP} / \mathrm{dt}$} & 18 and $30 \mathrm{w}$ & 4800 versus 4614 (18) and 5166 versus $5111 \mathrm{mmHg} / \mathrm{s}$ [30] NSD & {$[45]$} \\
\hline & $26 \mathrm{w}$ & NSD & {$[30]$} \\
\hline LVEDP & 18 and $30 \mathrm{w}$ & 8 versus $6[18]$ and 9 versus $6^{*}[30](\mathrm{mmHg})$ & {$[45]$} \\
\hline LVEDV & $20 \mathrm{w}$ & 550 versus $713 \mu \mathrm{l}$ NSD & {$[32]$} \\
\hline LVDV & $6 \mathrm{~m}$ & 411.69 versus $415.53 \mu \mathrm{l}$ NSD & {$[51]$} \\
\hline LVSV & $6 \mathrm{~m}$ & 108.51 versus $196.01^{*}(\mu \mathrm{l})$ & {$[51]$} \\
\hline \multirow{5}{*}{$\mathrm{EF}$} & $14-16 \mathrm{w}$ & 80 versus $73^{*}(\%)$ & {$[28]$} \\
\hline & $16 \mathrm{w}$ & NSD & {$[30]$} \\
\hline & $20 \mathrm{w}$ & 77.9 versus $80.5 \%$ NSD & [33] \\
\hline & $26 \mathrm{w}$ & 0.74 versus $0.93^{*}(\%)$ & {$[44]$} \\
\hline & $6 \mathrm{~m}$ & 73.42 versus $52.63^{*}(\%)$ & {$[51]$} \\
\hline \multirow{5}{*}{ FS } & $20 \mathrm{w}$ & 47 versus $30^{*}(\%)$ & {$[32]$} \\
\hline & $20 \mathrm{w}$ & 42.3 versus $45.3 \% \mathrm{NSD}$ & [33] \\
\hline & $24 \mathrm{w}$ & 43.45 versus $38.20 \% \mathrm{NSD}$ & {$[2]$} \\
\hline & $6 \mathrm{~m}$ & 44.41 versus $28.56^{*}(\%)$ & {$[51]$} \\
\hline & 18 and $30 \mathrm{w}$ & 51 versus $55[18]$ and 49 versus $51 \mathrm{~cm} \mathrm{[30]} \mathrm{NSD}$ & {$[45]$} \\
\hline
\end{tabular}


TABLe 6: Continued.

\begin{tabular}{lccc}
\hline Parameter & Age & Control versus GK & Reference \\
\hline CO & $20 \mathrm{w}$ & 368 versus $321 \mathrm{ml} / \mathrm{min} \mathrm{NSD}$ & {$[33]$} \\
& $6 \mathrm{~m}$ & 303.7 versus $219.52^{*}(\mu \mathrm{l})$ & {$[51]$} \\
\hline IVCT & $24 \mathrm{w}$ & 10.98 versus $12.26^{*}(\mathrm{~ms})$ & {$[2]$} \\
\hline \multirow{2}{*}{ IVRT } & $14-16 \mathrm{w}$ & 25.3 versus $28.3^{*}(\mathrm{~ms})$ & {$[2]$} \\
\hline CBF & $24 \mathrm{w}$ & 19.09 versus $24.88 \mathrm{~ms}$ & {$[29]$} \\
& $15 \mathrm{w}$ & Increased & \\
\hline
\end{tabular}

HR: heart rate; SBP: systolic blood pressure; DBP: diastolic blood pressure; MAP: mean arterial pressure; PLVP: peak left ventricular pressure; LV $+\mathrm{dP} / \mathrm{dt}$ : rate for pressure development in left ventricle; LV - dP/dt: rate for pressure decline in left ventricle; LVEDP: left ventricular end diastolic pressure; LVEDV: left ventricular end diastolic volume; LVDV: left ventricular diastolic volume; LVSV: left ventricular systolic volume; EF: ejection fraction; FS: fractional shortening; CO: cardiac output; IVCT: isovolumic contraction time; IVRT: isovolumic relaxation time; CBF: coronary blood flow; NSD: no significant difference. *Significant difference.

TABLE 7: Isolated heart hemodynamic function in the GK rat.

\begin{tabular}{|c|c|c|c|}
\hline Parameter & Age & Control versus GK & Reference \\
\hline \multirow{4}{*}{ HR } & $18 \mathrm{w}$ & 237 versus $213 \mathrm{bpm} \mathrm{NSF}$ & {$[31]$} \\
\hline & $5-8 \mathrm{~m}$ & 251.8 versus $259.5 \mathrm{bpm}$ NSD & {$[10]$} \\
\hline & $9-14 \mathrm{~m}$ & 267 versus 271 bpm NSD & {$[11]$} \\
\hline & $18 \mathrm{~m}$ & 138 versus 115 bpm NSD & {$[50]$} \\
\hline \multirow{2}{*}{ LVP } & $18 \mathrm{w}$ & 44 versus $52 \mathrm{mmHg} \mathrm{NSD}$ & {$[31]$} \\
\hline & $6 \mathrm{~m}$ & Reduced $^{*}$ & {$[51]$} \\
\hline \multirow{4}{*}{ LVDP } & $5-8 \mathrm{~m}$ & 126.6 versus $119.8 \mathrm{mmHg}$ NSD & {$[10]$} \\
\hline & $6 \mathrm{~m}$ & Reduced $^{*}$ & {$[51]$} \\
\hline & $16 \mathrm{w}$ & NSD & {$[35]$} \\
\hline & 9-14 m & 76 versus $63 \mathrm{mmHg}$ NSD & {$[11]$} \\
\hline $\mathrm{RPP}$ & $16 \mathrm{w}$ & NSD & {$[35]$} \\
\hline EDP & $9-14 \mathrm{~m}$ & 8 versus $10 \mathrm{mmHg}$ NSD & {$[11]$} \\
\hline \multirow{3}{*}{$\mathrm{LV}+\mathrm{dP} / \mathrm{dt}$} & $18 \mathrm{w}$ & 1365 versus $1602 \mathrm{mmHg} / \mathrm{s}$ NSD & {$[31]$} \\
\hline & $5-8 \mathrm{~m}$ & 3390.6 versus $3169.5 \mathrm{mmHg} / \mathrm{s}$ NSD & {$[10]$} \\
\hline & $6 \mathrm{~m}$ & Reduced $^{*}$ & {$[51]$} \\
\hline \multirow{3}{*}{$\mathrm{LV}-\mathrm{dP} / \mathrm{dt}$} & $18 \mathrm{w}$ & -945 versus $-1032 \mathrm{mmHg} / \mathrm{s}$ NSD & {$[31]$} \\
\hline & $5-8 \mathrm{~m}$ & -2669.0 versus $-2672.0 \mathrm{mmHg} / \mathrm{s} \mathrm{NSD}$ & {$[10]$} \\
\hline & $6 \mathrm{~m}$ & Reduced $^{*}$ & {$[51]$} \\
\hline \multirow{3}{*}{$\mathrm{CF}$} & $18 \mathrm{w}$ & 7.1 versus $5.8^{*}(\mathrm{ml} / \mathrm{min})$ & {$[31]$} \\
\hline & $5-8 \mathrm{~m}$ & 10.9 versus $9.8 \mathrm{ml} / \mathrm{min} / \mathrm{g} \mathrm{NSD}$ & {$[10]$} \\
\hline & $9-14 \mathrm{~m}$ & Reduced $^{*}$ & {$[11]$} \\
\hline $\mathrm{CPP}$ & $5-8 \mathrm{~m}$ & 74.2 versus $76.6 \mathrm{mmHg} \mathrm{NSD}$ & {$[10]$} \\
\hline
\end{tabular}

HR: heart rate; LVP: left ventricular pressure; LVDP: left ventricular developed pressure; RPP: rate pressure product; EDP: end diastolic pressure; $\mathrm{LV}+\mathrm{dP} / \mathrm{dt}$ : rate for pressure development in left ventricle; $\mathrm{LV}-\mathrm{dP} / \mathrm{dt}$ : rate for pressure decline in left ventricle; CF: coronary flow; CPP: coronary perfusion pressure; NSD: no significant difference. ${ }^{*}$ Significant difference.

It should be noted that the main function of the mitochondria in the heart is to produce energy in the form of ATP, which is required for cardiac contractile activity. However, mitochondria are known to serve as $\mathrm{Ca}^{2+}$ sinks in the cell by acting as a local buffering system, removing $\mathrm{Ca}^{2+}$ and modulating cytosolic $\mathrm{Ca}^{2+}$ concentrations $[65,109]$. In addition to controlling their intraorganelle $\mathrm{Ca}^{2+}$ concentration, mitochondria dynamically interact with the cytosol and intracellular $\mathrm{Ca}^{2+}$ handling machineries to shape the cellular $\mathrm{Ca}^{2+}$ signaling network [65]. Recent evidence suggests that there is a dynamic exchange of $\mathrm{Ca}^{2+}$ between the mitochondria and the cytosol and that mitochondrial $\mathrm{Ca}^{2+}$ uptake increases mitochondrial ATP production [110]. Therefore, mitochondria can play an important role in preventing and/or delaying the occurrence of intracellular $\mathrm{Ca}^{2+}$ overload in cardiomyocytes under 
TABle 8: Myocyte contraction from the GK rat heart.

\begin{tabular}{|c|c|c|c|}
\hline Parameter & Age & Control versus GK & Reference \\
\hline \multirow{2}{*}{$\mathrm{MD}$} & $8 \mathrm{w}$ & 9.11 versus $9.93^{*}(\mu \mathrm{m})$ & {$[36]$} \\
\hline & $18 \mathrm{~m}$ & 9.43 versus $11.34^{*}(\mu \mathrm{m})$ & {$[40]$} \\
\hline \multirow{2}{*}{ SA } & $16 \mathrm{w}$ & Increased* & {$[30]$} \\
\hline & $6 \mathrm{~m}$ & Increased $^{*}$ & {$[51]$} \\
\hline CSA & $20 \mathrm{w}$ & Increased $^{*}$ & {$[33]$} \\
\hline \multirow{6}{*}{ RCL } & $8-10 w$ & NSD & [41] \\
\hline & $5-8 \mathrm{~m}$ & NSD & {$[10]$} \\
\hline & $10 \mathrm{~m}$ & 139.48 versus $155.63^{*}(\mu \mathrm{m})$ & {$[47]$} \\
\hline & $10-11 \mathrm{~m}$ & Increased ${ }^{*}$ & {$[48]$} \\
\hline & $17 \mathrm{~m}$ & 109.7 versus $109.3 \mu \mathrm{m}$ NSD & [39] \\
\hline & $18 \mathrm{~m}$ & 139.8 versus $146.4 \mu \mathrm{m}$ NSD & {$[50]$} \\
\hline $\mathrm{CP}$ & $14-16 \mathrm{w}$ & Increased $^{*}$ & {$[28]$} \\
\hline \multirow{5}{*}{ TPK } & $8-10 w$ & 115.03 versus $125.38^{*}(\mathrm{~ms})$ & {$[41]$} \\
\hline & $10 \mathrm{~m}$ & 119.77 versus $136.15^{*}(\mathrm{~ms})$ & {$[47]$} \\
\hline & $10-11 \mathrm{~m}$ & NSD & [48] \\
\hline & $17 \mathrm{~m}$ & 302.7 versus $337.5^{*}(\mathrm{~ms})$ & [39] \\
\hline & $18 \mathrm{~m}$ & 119.9 versus $115.1 \mathrm{~ms}$ NSD & {$[50]$} \\
\hline \multirow{5}{*}{ THALF } & $8-10 w$ & NSD & {$[41]$} \\
\hline & $10 \mathrm{~m}$ & NSD & [47] \\
\hline & $10-11 \mathrm{~m}$ & NSD & {$[48]$} \\
\hline & $18 \mathrm{~m}$ & 75.2 versus $65.1^{*}(\mathrm{~ms})$ & {$[50]$} \\
\hline & $17 \mathrm{~m}$ & 231.3 versus $275.4^{*}(\mathrm{~ms})$ & {$[39]$} \\
\hline \multirow{6}{*}{ AMP } & $8-10 w$ & NSD & {$[41]$} \\
\hline & $5-8 \mathrm{~m}$ & NSD & {$[10]$} \\
\hline & $10 \mathrm{~m}$ & 6.52 versus $7.15 \%$ NSD & {$[47]$} \\
\hline & $10-11 \mathrm{~m}$ & NSD & {$[48]$} \\
\hline & $17 \mathrm{~m}$ & 5.05 versus $6.56^{*}(\%)$ & [39] \\
\hline & $18 \mathrm{~m}$ & 6.7 versus $6.5 \% \mathrm{NSD}$ & {$[50]$} \\
\hline
\end{tabular}

MD: myocyte diameter; SA: surface area; CSA: cross-sectional area; RCL: resting cell length; CP: cell capacitance; TPK: time to peak shortening; THALF: time to half relaxation of shortening; AMP: amplitude of shortening; NSD: no significant difference. ${ }^{*}$ Significant difference.

different pathological conditions. For example, during the development of cardiac dysfunction and intracellular $\mathrm{Ca}^{2+}$ overload in chronic diabetes, mitochondria are believed to continue accumulating $\mathrm{Ca}^{2+}$, thereby serving as a protective mechanism $[65,71]$. However, when the intramitochondrial $\mathrm{Ca}^{2+}$ concentration exceeds its buffering capacity, irreversible swelling occurs leading to mitochondrial dysfunction. As a result, energy production as well as energy stores are depleted. Collectively, these defects may contribute to the development of cardiac dysfunction in diabetic cardiomyopathy [109].

Evidence of deficits in mitochondrial $\mathrm{Ca}^{2+}$ handling has been demonstrated in animal models of both type 1 and type 2 diabetes. For example, in streptozotocin(STZ-) induced diabetic rats, hyperglycemia was associated with lower rates of mitochondrial $\mathrm{Ca}^{2+}$ uptake [107]. This reduction can be explained by the increased opening of
TABle 9: Myocyte calcium from the GK rat heart.

\begin{tabular}{|c|c|c|c|}
\hline Parameter & Age & Control versus GK & Reference \\
\hline \multirow{7}{*}{$\mathrm{RCa}^{2+}$} & $14-16 \mathrm{w}$ & 0.97 versus $1.25^{*}(\mathrm{RU})$ & {$[28]$} \\
\hline & $8-10 w$ & NSD & {$[41]$} \\
\hline & $5-8 \mathrm{~m}$ & NSD & {$[10]$} \\
\hline & $10 \mathrm{~m}$ & NSD & [47] \\
\hline & $10-11 \mathrm{~m}$ & NSD & {$[48]$} \\
\hline & $17 \mathrm{~m}$ & 1.32 versus 1.23 RU NSD & [39] \\
\hline & $18 \mathrm{~m}$ & 1.28 versus 1.31 RU NSD & {$[50]$} \\
\hline \multirow{5}{*}{ TPK } & $8-10 w$ & NSD & {$[41]$} \\
\hline & $10 \mathrm{~m}$ & 55.82 versus $66.14^{*}(\mathrm{~ms})$ & {$[47]$} \\
\hline & $10-11 \mathrm{~m}$ & NSD & {$[48]$} \\
\hline & $17 \mathrm{~m}$ & 91.7 versus $104.3 \mathrm{~ms}$ NSD & {$[39]$} \\
\hline & $18 \mathrm{~m}$ & 64.8 versus $66.6 \mathrm{~ms}$ NSD & {$[50]$} \\
\hline \multirow{5}{*}{ THALF } & $8-10 w$ & 183.46 versus $148.32 *(\mathrm{~ms})$ & {$[41]$} \\
\hline & $10 \mathrm{~m}$ & NSD & [47] \\
\hline & $10-11 \mathrm{~m}$ & NSD & {$[48]$} \\
\hline & $17 \mathrm{~m}$ & 199.1 versus $199.0 \mathrm{~ms}$ NSD & [39] \\
\hline & $18 \mathrm{~m}$ & 136.2 versus $123.1 \mathrm{~ms}$ NSD & {$[50]$} \\
\hline \multirow{6}{*}{ AMP } & $8-10 w$ & NSD & {$[41]$} \\
\hline & $5-8 \mathrm{~m}$ & NSD & {$[10]$} \\
\hline & $10 \mathrm{~m}$ & 0.25 versus $0.31(\mathrm{RU})$ & {$[47]$} \\
\hline & $10-11 \mathrm{~m}$ & NSD & {$[48]$} \\
\hline & $17 \mathrm{~m}$ & 0.30 versus $0.23^{*}(\mathrm{RU})$ & [39] \\
\hline & $18 \mathrm{~m}$ & 0.50 versus $0.78^{*}(\mathrm{RU})$ & {$[50]$} \\
\hline ICaL amplitude & $10-11 \mathrm{~m}$ & NSD & {$[48]$} \\
\hline $\begin{array}{l}\mathrm{ICaL} \\
\text { inactivation }\end{array}$ & $10-11 \mathrm{~m}$ & NSD & {$[48]$} \\
\hline ICaL restitution & $10-11 \mathrm{~m}$ & NSD & {$[48]$} \\
\hline $\mathrm{MS} \mathrm{Ca}^{2+}$ & $17 \mathrm{~m}$ & 31.9 versus $89.2^{*}(\mu \mathrm{m} / \mathrm{RU})$ & {$[39]$} \\
\hline
\end{tabular}

the mitochondrial permeability transition pore (MPTP), resulting in the release of accumulated $\mathrm{Ca}^{2+}$. In STZinduced diabetic rats, Oliveira et al. observed that $\mathrm{Ca}^{2+}$ uptake was similar in control versus diabetic hearts; however, mitochondria in diabetic hearts were unable to retain the accumulated $\mathrm{Ca}^{2+}$. This effect was not observed in the presence of cyclosporin, an MPTP inhibitor [108]. In type 2 diabetic ob/ob mice, reduced intracellular $\mathrm{Ca}^{2+}$ release upon electrical stimulation, slowed intracellular $\mathrm{Ca}^{2+}$ decay rate, and impaired mitochondrial $\mathrm{Ca}^{2+}$ handling were observed [111, 112]. Similarly, Belke et al. observed a reduction in $\mathrm{Ca}^{2+}$ levels and a reduction in the rate of $\mathrm{Ca}^{2+}$ decay in isolated cardiomyocytes from $d b / d b$ animals, suggesting impaired mitochondrial $\mathrm{Ca}^{2+}$ uptake [113]. Taken together, these studies support the notion that mitochondrial $\mathrm{Ca}^{2+}$ handling is impaired in diabetic myocardium, resulting in compromised energy metabolism and thus reduced contractility. 


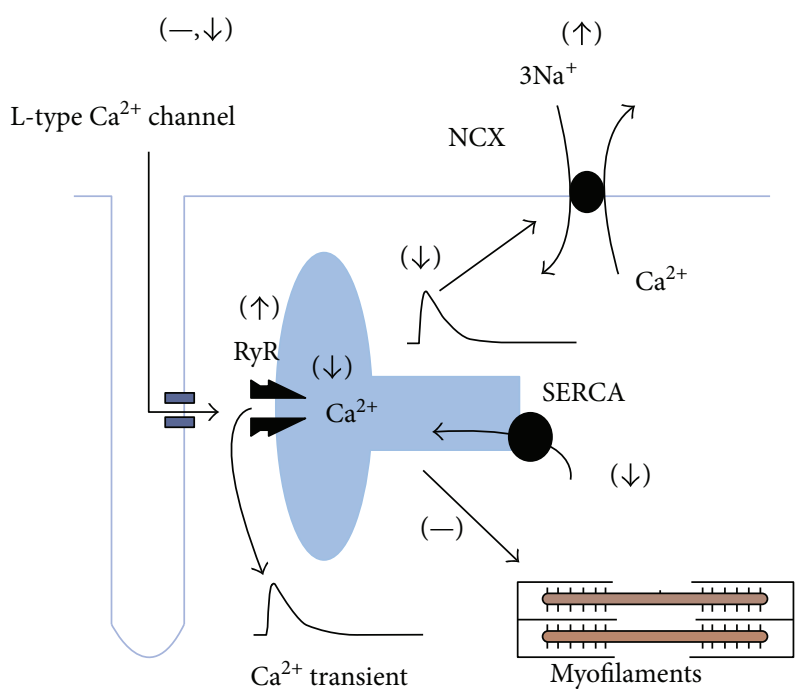

FIGURE 1: Schematic diagram showing the summary of some of the proposed mechanisms involved in the alterations in $\mathrm{Ca}^{2+}$ signaling in cardiac myocyte from the GK diabetic heart. (1) No change/or decrease in L-type $\mathrm{Ca}^{2+}$ channel activity, (2) increase in $\mathrm{Na}^{+} / \mathrm{Ca}^{2+}$ exchange current, (3) decrease in SR $\mathrm{Ca}^{2+}$ content, (4) decrease in $\mathrm{SR} \mathrm{Ca}^{2+}$ uptake, and (5) increase in $\mathrm{Ca}^{2+}$ release through RYR. SR: sarcoplasmic reticulum; RYR: ryanodine receptor; SERCA: sarcoplasmic reticulum $\mathrm{Ca}^{2+}$-ATPase; NCX: $\mathrm{Na}^{+} / \mathrm{Ca}^{2+}$ exchanger; -: no effect; $\uparrow$ : increased activity; $\downarrow$ : decreased activity (adapted from Eisner, 2013).

\section{Conclusion}

Although diabetic cardiomyopathy is a frequent and important complication of DM, its physiological bases are still not completely understood. The GK type 2 diabetic heart displays a variety of abnormal hemodynamic characteristics in vivo and in the isolated perfused heart. Hyperglycemia is usually associated with alterations in heart rate, blood pressure, blood pumping capability, and/or coronary blood flow. Contractile function, in terms of amplitude and kinetics of shortening, is frequently disturbed in the GK type 2 diabetic heart. Several mechanisms may contribute to cardiac dysfunction including mitochondrial dysfunction, myocardial fibrosis, hypertrophy, and apoptosis. Many studies show no change in L-type $\mathrm{Ca}^{2+}$ current despite the reduction in both contractions and $\mathrm{Ca}^{2+}$ transient. Instead, reduction of $\mathrm{Ca}^{2+}$ transients and the consequent contractile dysfunction may be attributed to both depletion of SR $\mathrm{Ca}^{2+}$, which may result from RyR-dependent $\mathrm{Ca}^{2+}$ leak, an increased $\mathrm{Ca}^{2+}$ extrusion through NCX, or a reduced function of SERCA (Figure 1). Understanding the molecular mechanism(s) of altered $\mathrm{Ca}^{2+}$ signaling will provide opportunities for the development of new treatments to improve heart function in T2DM patients.

\section{Abbreviations}

DM: $\quad$ Diabetes mellitus

CVDs: Cardiovascular diseases

T2DM: Type 2 diabetes mellitus

GK: $\quad$ Goto-Kakizaki
GLUT-2: Glucose transporter

GPDH: Glycerol-3-phosphate dehydrogenase

NZO: $\quad$ New Zealand obese

OLETF: Otsuka Long Evans Tokushima Fat

SDT: $\quad$ Spontaneously diabetic Torri

TGF- $\beta 1$ : Transforming growth factor- $\beta 1$

ECM: $\quad$ Extracellular matrix

PKB: $\quad$ Protein kinase B

ECC: $\quad$ Excitation-contraction coupling

SR: $\quad$ Sarcoplasmic reticulum

RyR: Ryanodine receptor

CICR: Calcium-induced calcium release

SERCA2: SR Ca ${ }^{2+}$-ATPase2

NCX: $\quad \mathrm{Na}^{+} / \mathrm{Ca}^{2+}$ exchanger

ENDO: Endocardial

EPI: $\quad$ Epicardial.

\section{Conflicts of Interest}

The authors declare that there is no conflict of interest regarding the publication of this article.

\section{Acknowledgments}

The research reported in this article was supported by grants from the College of Medicine and Health Sciences, United Arab Emirates University, Al Ain; United Arab Emirates University, Al Ain; Sheikh Hamdan Bin Rashid Al Maktoum Award for Medical Sciences, Dubai; and Zayed University, Abu Dhabi.

\section{References}

[1] Y. Goto, M. Kakizaki, and N. Masaki, "Spontaneous diabetes produced by selective breeding of normal Wistar rats," Proceedings of the Japan Academy, vol. 51, pp. 80-85, 1975.

[2] S. Devanathan, S. T. Nemanich, A. Kovacs, N. Fettig, R. J. Gropler, and K. I. Shoghi, "Genomic and metabolic disposition of non-obese type 2 diabetic rats to increased myocardial fatty acid metabolism," PLoS One, vol. 8, no. 10, article e78477, 2013.

[3] B. Portha, P. Serradas, D. Bailbe, K. Suzuki, Y. Goto, and M. H. Giroix, " $\beta$-cell insensitivity to glucose in the GK rat, a spontaneous nonobese model for type II diabetes," Diabetes, vol. 40, no. 4, pp. 486-491, 1991.

[4] S. Bisbis, D. Bailbe, M. A. Tormo et al., "Insulin resistance in the GK rat: decreased receptor number but normal kinase activity in liver," American Journal of Physiology Endocrinology and Metabolism, vol. 265, no. 5, pp. E807-E813, 1993.

[5] C. G. Östenson, A. Khan, S. M. Abdel-Halim et al., "Abnormal insulin secretion and glucose metabolism in pancreatic islets from the spontaneously diabetic GK rat," Diabetologia, vol. 36, no. 1, pp. 3-8, 1993.

[6] D. Gauguier, I. Nelson, C. Bernard et al., "Higher maternal than paternal inheritance of diabetes in GK rats," Diabetes, vol. 43, no. 2, pp. 220-224, 1994.

[7] S. J. Hughes, K. Suzuki, and Y. Goto, "The role of islet secretory function in the development of diabetes in the GK Wistar rat," Diabetologia, vol. 37, no. 9, pp. 863-870, 1994. 
[8] C. Villar-Palasi and R. V. Farese, "Impaired skeletal muscle glycogen synthase activation by insulin in the GotoKakizaki (G/K) rat," Diabetologia, vol. 37, no. 9, pp. 885888, 1994.

[9] Y. Murakawa, W. Zhang, C. R. Pierson et al., "Impaired glucose tolerance and insulinopenia in the GK-rat causes peripheral neuropathy," Diabetes/Metabolism Research and Reviews, vol. 18, no. 6, pp. 473-483, 2002.

[10] M. M. El Omar, Z. K. Yang, A. O. Phillips, and A. M. Shah, "Cardiac dysfunction in the Goto-Kakizaki rat: a model of type II diabetes mellitus," Basic Research in Cardiology, vol. 99, no. 2, pp. 133-141, 2004.

[11] M. Desrois, K. Clarke, C. Lan et al., "Upregulation of eNOS and unchanged energy metabolism in increased susceptibility of the aging type 2 diabetic GK rat heart to ischemic injury," American Journal of Physiology Heart and Circulatory Physiology, vol. 299, no. 5, pp. H1679-H1686, 2010.

[12] M. S. Akash, K. Rehman, and S. Chen, "Goto-Kakizaki rats: its suitability as non-obese diabetic animal model for spontaneous type 2 diabetes mellitus," Current Diabetes Reviews, vol. 9, no. 5, pp. 387-396, 2013.

[13] A. Chatzigeorgiou, A. Halapas, K. Kalafatakis, and E. Kamper, "The use of animal models in the study of diabetes mellitus," In Vivo, vol. 23, no. 2, pp. 245-258, 2009.

[14] B. Portha, M. H. Giroix, C. Tourrel-Cuzin, H. Le-Stunff, and J. Movassat, "The GK rat: a prototype for the study of nonoverweight type 2 diabetes," in Animal Models in Diabetes Research, H. G. Joost, H. Al-Hasani, and A. Schürmann, Eds., vol. 933 of Methods in Molecular Biology, pp. 125159, Humana Press, Totowa, NJ, USA, 2012.

[15] A. J. King, "The use of animal models in diabetes research," British Journal of Pharmacology, vol. 166, no. 3, pp. 877894, 2012.

[16] P. Masiello, "Animal models of type 2 diabetes with reduced pancreatic beta-cell mass," The International Journal of Biochemistry \& Cell Biology, vol. 38, no. 5-6, pp. 873893, 2006.

[17] F. Homo-Delarche, S. Calderari, J. C. Irminger et al., "Islet inflammation and fibrosis in a spontaneous model of type 2 diabetes, the GK rat," Diabetes, vol. 55, no. 6, pp. 16251633, 2006.

[18] S. M. Mauer, M. W. Steffes, E. N. Ellis, D. E. Sutherland, D. M. Brown, and F. C. Goetz, "Structural-functional relationships in diabetic nephropathy," The Journal of Clinical Investigation, vol. 74, no. 4, pp. 1143-1155, 1984.

[19] A. O. Phillips, K. Baboolal, S. Riley et al., "Association of prolonged hyperglycemia with glomerular hypertrophy and renal basement membrane thickening in the Goto Kakizaki model of non-insulin-dependent diabetes mellitus," American Journal of Kidney Diseases, vol. 37, no. 2, pp. 400410, 2001.

[20] N. Sato, K. Komatsu, and H. Kurumatani, "Late onset of diabetic nephropathy in spontaneously diabetic GK rats," American Journal of Nephrology, vol. 23, no. 5, pp. 334342, 2003.

[21] M. Prentki and C. J. Nolan, "Islet $\beta$ cell failure in type 2 diabetes," The Journal of Clinical Investigation, vol. 116, no. 7 , pp. 1802-1812, 2006.

[22] B. B. Kahn and J. S. Flier, "Obesity and insulin resistance," The Journal of Clinical Investigation, vol. 106, no. 4, pp. 473-481, 2000.
[23] A. King and J. Bowe, "Animal models for diabetes: understanding the pathogenesis and finding new treatments," Biochemical Pharmacology, vol. 99, pp. 1-10, 2016.

[24] Y. Goto, M. Kakizaki, and N. Masaki, "Production of spontaneous diabetic rats by repetition of selective breeding," The Tohoku Journal of Experimental Medicine, vol. 119, no. 1, pp. 85-90, 1976.

[25] B. Portha, M. H. Giroix, P. Serradas et al., "Beta-cell function and viability in the spontaneously diabetic GK rat: information from the GK/Par colony," vol. 50, Supplement 1, pp. S89-S93, 2001.

[26] C. G. Ostenson and S. Efendic, "Islet gene expression and function in type 2 diabetes; studies in the Goto-Kakizaki rat and humans," Diabetes, Obesity and Metabolism, vol. 9, Supplement 2, pp. 180-186, 2007.

[27] F. Miralles and B. Portha, "Early development of beta-cells is impaired in the GK rat model of type 2 diabetes," Diabetes, vol. 50, Supplement 1, pp. S84-S88, 2001.

[28] A. Darmellah, D. Baetz, F. Prunier, S. Tamareille, C. Rucker-Martin, and D. Feuvray, "Enhanced activity of the myocardial $\mathrm{Na}^{+} / \mathrm{H}^{+}$exchanger contributes to left ventricular hypertrophy in the Goto-Kakizaki rat model of type 2 diabetes: critical role of Akt," Diabetologia, vol. 50, no. 6, pp. 1335-1344, 2007.

[29] M. Sarkozy, G. Szucs, V. Fekete et al., "Transcriptomic alterations in the heart of non-obese type 2 diabetic GotoKakizaki rats," Cardiovascular Diabetology, vol. 15, no. 1, p. 110, 2016.

[30] S. Korkmaz-Icoz, A. Lehner, S. Li et al., "Mild type 2 diabetes mellitus reduces the susceptibility of the heart to ischemia/ reperfusion injury: identification of underlying gene expression changes," Journal of Diabetes Research, vol. 2015, Article ID 396414, 16 pages, 2015.

[31] E. Liepinsh, R. Vilskersts, L. Zvejniece et al., "Protective effects of mildronate in an experimental model of type 2 diabetes in Goto-Kakizaki rats," British Journal of Pharmacology, vol. 157, no. 8, pp. 1549-1556, 2009.

[32] T. Gronholm, Z. J. Cheng, E. Palojoki et al., "Vasopeptidase inhibition has beneficial cardiac effects in spontaneously diabetic Goto-Kakizaki rats," European Journal of Pharmacology, vol. 519, no. 3, pp. 267-276, 2005.

[33] E. Vahtola, M. Louhelainen, H. Forsten et al., "Sirtuin1-p53, forkhead box O3a, p38 and post-infarct cardiac remodeling in the spontaneously diabetic Goto-Kakizaki rat," Cardiovascular Diabetology, vol. 9, no. 1, p. 5, 2010.

[34] K. Witte, K. Jacke, R. Stahrenberg et al., "Dysfunction of soluble guanylyl cyclase in aorta and kidney of GotoKakizaki rats: influence of age and diabetic state," Nitric Oxide, vol. 6, no. 1, pp. 85-95, 2002.

[35] S. B. Kristiansen, B. Løfgren, N. B. Støttrup et al., "Ischaemic preconditioning does not protect the heart in obese and lean animal models of type 2 diabetes," Diabetologia, vol. 47, no. 10, pp. 1716-1721, 2004.

[36] A. D’Souza, F. C. Howarth, J. Yanni et al., "Left ventricle structural remodelling in the prediabetic Goto-Kakizaki rat," Experimental Physiology, vol. 96, no. 9, pp. 875888, 2011.

[37] Z. J. Cheng, T. Vaskonen, I. Tikkanen et al., "Endothelial dysfunction and salt-sensitive hypertension in spontaneously diabetic Goto-Kakizaki rats," Hypertension, vol. 37, no. 2, pp. 433-439, 2001. 
[38] J. Crisostomo, P. Matafome, D. Santos-Silva et al., "Methylglyoxal chronic administration promotes diabeteslike cardiac ischaemia disease in Wistar normal rats," Nutrition, Metabolism \& Cardiovascular Diseases, vol. 23, no. 12, pp. 1223-1230, 2013.

[39] F. C. Howarth and M. A. Qureshi, "Myofilament sensitivity to $\mathrm{Ca}^{2+}$ in ventricular myocytes from the Goto-Kakizaki diabetic rat," Molecular and Cellular Biochemistry, vol. 315, no. 1-2, pp. 69-74, 2008.

[40] A. D'Souza, F. C. Howarth, J. Yanni et al., "Chronic effects of mild hyperglycaemia on left ventricle transcriptional profile and structural remodelling in the spontaneously type 2 diabetic Goto-Kakizaki rat," Heart Failure Reviews, vol. 19, no. 1, pp. 65-74, 2014.

[41] K. A. Salem, T. E. Adrian, M. A. Qureshi, K. Parekh, M. Oz, and F. C. Howarth, "Shortening and intracellular $\mathrm{Ca}^{2+}$ in ventricular myocytes and expression of genes encoding cardiac muscle proteins in early onset type 2 diabetic GotoKakizaki rats," Experimental Physiology, vol. 97, no. 12, pp. 1281-1291, 2012.

[42] C. Jurysta, C. Nicaise, M. H. Giroix, S. Cetik, W. J. Malaisse, and A. Sener, "Comparison of GLUT1, GLUT2, GLUT4 and SGLT1 mRNA expression in the salivary glands and six other organs of control, streptozotocin-induced and GotoKakizaki diabetic rats," Cellular Physiology and Biochemistry, vol. 31, no. 1, pp. 37-43, 2013.

[43] J. Radosinska, L. H. Kurahara, K. Hiraishi et al., "Modulation of cardiac connexin- 43 by omega-3 fatty acid ethyl-ester supplementation demonstrated in spontaneously diabetic rats," Physiological Research, vol. 64, no. 6, pp. 795-806, 2015.

[44] B. Picatoste, E. Ramírez, A. Caro-Vadillo et al., "Sitagliptin reduces cardiac apoptosis, hypertrophy and fibrosis primarily by insulin-dependent mechanisms in experimental type-II diabetes. Potential roles of GLP-1 isoforms," PLoS One, vol. 8, no. 10, article e78330, 2013.

[45] M. P. Chandler, E. E. Morgan, T. A. McElfresh et al., "Heart failure progression is accelerated following myocardial infarction in type 2 diabetic rats," American Journal of Physiology Heart and Circulatory Physiology, vol. 293, no. 3, pp. H1609-H1616, 2007.

[46] F. C. Howarth, M. Jacobson, M. Shafiullah, and E. ADEGHATE, "Long-term effects of type 2 diabetes mellitus on heart rhythm in the Goto-Kakizaki rat," Experimental Physiology, vol. 93, no. 3, pp. 362-369, 2008.

[47] E. M. Gaber, P. Jayaprakash, M. A. Qureshi et al., "Effects of a sucrose-enriched diet on the pattern of gene expression, contraction and $\mathrm{Ca}^{2+}$ transport in Goto-Kakizaki type 2 diabetic rat heart," Experimental Physiology, vol. 99, no. 6, pp. 881893, 2014.

[48] K. A. Salem, M. A. Qureshi, V. Sydorenko et al., "Effects of exercise training on excitation-contraction coupling and related mRNA expression in hearts of Goto-Kakizaki type 2 diabetic rats," Molecular and Cellular Biochemistry, vol. 380, no. 1-2, pp. 83-96, 2013.

[49] D. L. Santos, C. M. Palmeira, R. Seica et al., "Diabetes and mitochondrial oxidative stress: a study using heart mitochondria from the diabetic Goto-Kakizaki rat," Molecular and Cellular Biochemistry, vol. 246, no. 1-2, pp. 163-170, 2003.

[50] F. C. Howarth, M. Shafiullah, and M. A. Qureshi, "Chronic effects of type 2 diabetes mellitus on cardiac muscle contraction in the Goto-Kakizaki rat," Experimental Physiology, vol. 92, no. 6, pp. 1029-1036, 2007.
[51] X. Yu, Q. Zhang, W. Cui et al., "Low molecular weight fucoidan alleviates cardiac dysfunction in diabetic GotoKakizaki rats by reducing oxidative stress and cardiomyocyte apoptosis," Journal of Diabetes Research, vol. 2014, Article ID 420929, 13 pages, 2014.

[52] R. Ramos-Mondragon, C. A. Galindo, and G. Avila, "Role of TGF- $\beta$ on cardiac structural and electrical remodeling," Vascular Health and Risk Management, vol. 4, no. 6, pp. 1289-1300, 2008.

[53] A. Desmouliere, A. Geinoz, F. Gabbiani, and G. Gabbiani, "Transforming growth factor-beta 1 induces alpha-smooth muscle actin expression in granulation tissue myofibroblasts and in quiescent and growing cultured fibroblasts," Journal of Cell Biology, vol. 122, no. 1, pp. 103-111, 1993.

[54] C. S. Long, "Autocrine and paracrine regulation of myocardial cell growth in vitro the TGF $\beta$ paradigm," Trends in Cardiovascular Medicine, vol. 6, no. 7, pp. 217-226, 1996.

[55] A. P. Sappino, I. Masouye, J. H. Saurat, and G. Gabbiani, "Smooth muscle differentiation in scleroderma fibroblastic cells," The American Journal of Pathology, vol. 137, no. 3, pp. 585-591, 1990.

[56] G. A. Walker, K. S. Masters, D. N. Shah, K. S. Anseth, and L. A. Leinwand, "Valvular myofibroblast activation by transforming growth factor- $\beta$ : implications for pathological extracellular matrix remodeling in heart valve disease," Circulation Research, vol. 95, no. 3, pp. 253-260, 2004.

[57] M. Desrois, R. J. Sidell, D. Gauguier, C. L. Davey, G. K. Radda, and K. Clarke, "Gender differences in hypertrophy, insulin resistance and ischemic injury in the aging type 2 diabetic rat heart," Journal of Molecular and Cellular Cardiology, vol. 37, no. 2, pp. 547-555, 2004.

[58] H. Yang, M. D. Nyby, Y. Ao et al., "Role of brainstem thyrotropin-releasing hormone-triggered sympathetic overactivation in cardiovascular mortality in type 2 diabetic Goto-Kakizaki rats," Hypertension Research, vol. 35, no. 2, pp. 157-165, 2011.

[59] A. F. Ceylan-Isik, K. H. LaCour, and J. Ren, "Sex difference in cardiomyocyte function in normal and metallothionein transgenic mice: the effect of diabetes mellitus," Journal of Applied Physiology, vol. 100, no. 5, pp. 16381646, 2006.

[60] F. Brette, J. Leroy, J. Y. Le Guennec, and L. Salle, "Ca ${ }^{2+}$ currents in cardiac myocytes: old story, new insights," Progress in Biophysics and Molecular Biology, vol. 91, no. 1-2, pp. 1-82, 2006.

[61] D. M. Bers, "Cardiac excitation-contraction coupling," Nature, vol. 415, no. 6868, pp. 198-205, 2002.

[62] J. Patel, A. Iyer, and L. Brown, "Evaluation of the chronic complications of diabetes in a high fructose diet in rats," Indian Journal of Biochemistry and Biophysics, vol. 46, no. 1, pp. 66-72, 2009.

[63] C. Rickman, A. Iyer, V. Chan, and L. Brown, "Green tea attenuates cardiovascular remodeling and metabolic symptoms in high carbohydrate-fed rats," Current Pharmaceutical Biotechnology, vol. 11, no. 8, pp. 881-886, 2010.

[64] Y. Hattori, N. Matsuda, J. Kimura et al., "Diminished function and expression of the cardiac $\mathrm{Na}^{+}-\mathrm{Ca}_{2}{ }^{+}$exchanger in diabetic rats: implication in $\mathrm{Ca}^{+}{ }^{+}$overload," The Journal of Physiology, vol. 527, no. 1, pp. 85-94, 2000.

[65] N. S. Dhalla, S. Rangi, S. Zieroth, and Y. J. Xu, "Alterations in sarcoplasmic reticulum and mitochondrial functions in 
diabetic cardiomyopathy," Experimental \& Clinical Cardiology, vol. 17, no. 3, pp. 115-120, 2012.

[66] N. S. Dhalla, P. K. Das, and G. P. Sharma, "Subcellular basis of cardiac contractile failure," Journal of Molecular and Cellular Cardiology, vol. 10, no. 4, pp. 363-385, 1978.

[67] S. Penpargkul, F. Fein, E. H. Sonnenblick, and J. Scheuer, "Depressed cardiac sarcoplasmic reticular function from diabetic rats," Journal of Molecular and Cellular Cardiology, vol. 13, no. 3, pp. 303-309, 1981.

[68] P. K. Ganguly, G. N. Pierce, K. S. Dhalla, and N. S. Dhalla, "Defective sarcoplasmic reticular calcium transport in diabetic cardiomyopathy," American Journal of Physiology Endocrinology and Metabolism, vol. 244, no. 6, pp. E528E535, 1983.

[69] G. D. Lopaschuk, A. G. Tahiliani, R. V. Vadlamudi, S. Katz, and J. H. Mcneill, "Cardiac sarcoplasmic reticulum function in insulin- or carnitine-treated diabetic rats," American Journal of Physiology Heart and Circulatory Physiology, vol. 245, no. 6, pp. H969-H976, 1983.

[70] N. S. Dhalla, G. N. Pierce, I. R. Innes, and R. E. Beamish, "Pathogenesis of cardiac dysfunction in diabetes mellitus," The Canadian Journal of Cardiology, vol. 1, no. 4, pp. 263281, 1985.

[71] N. S. Dhalla, X. Liu, V. Panagia, and N. Takeda, "Subcellular remodeling and heart dysfunction in chronic diabetes," Cardiovascular Research, vol. 40, no. 2, pp. 239-247, 1998.

[72] L. S. Golfman, N. Takeda, and N. S. Dhalla, "Cardiac membrane $\mathrm{Ca}^{2+}$-transport in alloxan-induced diabetes in rats," Diabetes Research and Clinical Practice, vol. 31, pp. S73S77, 1996.

[73] Z. Yu, G. F. Tibbits, and J. H. Mcneill, "Cellular functions of diabetic cardiomyocytes: contractility, rapid-cooling contracture, and ryanodine binding," American Journal of Physiology Heart and Circulatory Physiology, vol. 266, no. 5, pp. H2082H2089, 1994.

[74] L. Al Kury, V. Sydorenko, M. M. A. Smail et al., "Voltage dependence of the $\mathrm{Ca}^{2+}$ transient in endocardial and epicardial myocytes from the left ventricle of Goto-Kakizaki type 2 diabetic rats," Molecular and Cellular Biochemistry, vol. 9, pp. 10-3269, 2018.

[75] L. Pereira, J. Matthes, I. Schuster et al., "Mechanisms of $\left[\mathrm{Ca}^{2+}\right] \mathrm{i}$ transient decrease in cardiomyopathy of $d b / d b$ type 2 diabetic mice," Diabetes, vol. 55, no. 3, pp. 608-615, 2006.

[76] Z. Lu, Y. P. Jiang, X. H. Xu, L. M. Ballou, I. S. Cohen, and R. Z. Lin, "Decreased L-type $\mathrm{Ca}^{2+}$ current in cardiac myocytes of type 1 diabetic Akita mice due to reduced phosphatidylinositol 3-kinase signaling," Diabetes, vol. 56, no. 11, pp. 2780-2789, 2007.

[77] S. Kaab, H. B. Nuss, N. Chiamvimonvat et al., "Ionic mechanism of action potential prolongation in ventricular myocytes from dogs with pacing-induced heart failure," Circulation Research, vol. 78, no. 2, pp. 262-273, 1996.

[78] A. M. Gomez, H. H. Valdivia, H. Cheng et al., "Defective excitation-contraction coupling in experimental cardiac hypertrophy and heart failure," Science, vol. 276, no. 5313, pp. 800-806, 1997.

[79] M. M. Smail, M. A. Qureshi, A. Shmygol et al., "Regional effects of streptozotocin-induced diabetes on shortening and calcium transport in epicardial and endocardial myocytes from rat left ventricle," Physiological Reports, vol. 4, no. 22 , article e13034, 2016.
[80] X. H. Wehrens, S. E. Lehnart, and A. R. Marks, "Intracellular calcium release and cardiac disease," Annual Review of Physiology, vol. 67, no. 1, pp. 69-98, 2005.

[81] A. Q. Sheikh, J. R. Hurley, W. Huang et al., "Diabetes alters intracellular calcium transients in cardiac endothelial cells," PLoS One, vol. 7, no. 5, article e36840, 2012.

[82] D. Lagadic-Gossmann, K. J. Buckler, K. Le Prigent, and D. Feuvray, "Altered $\mathrm{Ca} 2+$ handling in ventricular myocytes isolated from diabetic rats," American Journal of Physiology Heart and Circulatory Physiology, vol. 270, no. 5, pp. H1529-H1537, 1996.

[83] K. M. Choi, Y. Zhong, B. D. Hoit et al., "Defective intracellular $\mathrm{Ca}^{2+}$ signaling contributes to cardiomyopathy in type 1 diabetic rats," American Journal of Physiology Heart and Circulatory Physiology, vol. 283, no. 4, pp. H1398-H1408, 2002.

[84] J. Z. Yu, G. A. Quamme, and J. H. Mcneill, "Altered $\left[\mathrm{Ca}^{2+}\right]_{\mathrm{i}}$ mobilization in diabetic cardiomyocytes: responses to caffeine, $\mathrm{KCl}$, ouabain, and ATP," Diabetes Research and Clinical Practice, vol. 30, no. 1, pp. 9-20, 1995.

[85] N. Yaras, M. Ugur, S. Ozdemir et al., "Effects of diabetes on ryanodine receptor ca release channel (RyR2) and $\mathrm{Ca}^{2+}$ homeostasis in rat heart," Diabetes, vol. 54, no. 11, pp. 3082-3088, 2005.

[86] N. Yaras, A. Bilginoglu, G. Vassort, and B. Turan, "Restoration of diabetes-induced abnormal local $\mathrm{Ca}^{2+}$ release in cardiomyocytes by angiotensin II receptor blockade," American Journal of Physiology Heart and Circulatory Physiology, vol. 292, no. 2, pp. H912-H920, 2007.

[87] C. H. Shao, G. J. Rozanski, K. P. Patel, and K. R. Bidasee, "Dyssynchronous (non-uniform) $\mathrm{Ca}^{2+}$ release in myocytes from streptozotocin-induced diabetic rats," Journal of Molecular and Cellular Cardiology, vol. 42, no. 1, pp. 234246, 2007.

[88] V. A. Lacombe, S. Viatchenko-Karpinski, D. Terentyev et al., "Mechanisms of impaired calcium handling underlying subclinical diastolic dysfunction in diabetes," American Journal of Physiology Regulatory, Integrative and Comparative Physiology, vol. 293, no. 5, pp. R1787-R1797, 2007.

[89] C. H. Shao, X. H. Wehrens, T. A. Wyatt et al., "Exercise training during diabetes attenuates cardiac ryanodine receptor dysregulation," Journal of Applied Physiology, vol. 106, no. 4, pp. 1280-1292, 2009.

[90] T. I. Lee, Y. C. Chen, Y. H. Kao, F. C. Hsiao, Y. K. Lin, and Y. J. Chen, "Rosiglitazone induces arrhythmogenesis in diabetic hypertensive rats with calcium handling alteration," International Journal of Cardiology, vol. 165, no. 2, pp. 299307, 2013.

[91] A. L. Kranstuber, R. C. Del, B. J. Biesiadecki et al., "Advanced glycation end product cross-link breaker attenuates diabetesinduced cardiac dysfunction by improving sarcoplasmic reticulum calcium handling," Frontiers in Physiology, vol. 3, p. 292, 2012.

[92] N. Afzal, G. N. Pierce, V. Elimban, R. E. Beamish, and N. S. Dhalla, "Influence of verapamil on some subcellular defects in diabetic cardiomyopathy," American Journal of Physiology Endocrinology and Metabolism, vol. 256, no. 4, pp. E453E458, 1989.

[93] N. Takeda, I. C. Dixon, T. Hata, V. Elimban, K. R. Shah, and N. S. Dhalla, "Sequence of alterations in subcellular organelles during the development of heart dysfunction in diabetes," Diabetes Research and Clinical Practice, vol. 30, Supplement 1, pp. S113-S122, 1996. 
[94] F. L. Norby, L. E. Wold, J. Duan, K. K. Hintz, and J. Ren, "IGF-I attenuates diabetes-induced cardiac contractile dysfunction in ventricular myocytes," American Journal of Physiology Endocrinology and Metabolism, vol. 283, no. 4, pp. E658-E666, 2002.

[95] C. J. Moore, C. H. Shao, R. Nagai, S. Kutty, J. Singh, and K. R. Bidasee, "Malondialdehyde and 4-hydroxynonenal adducts are not formed on cardiac ryanodine receptor (RyR2) and sarco(endo)plasmic reticulum $\mathrm{Ca}^{2+}$-ATPase (SERCA2) in diabetes," Molecular and Cellular Biochemistry, vol. 376, no. 1-2, pp. 121-135, 2013.

[96] P. K. Mazumder, B. T. O'Neill, M. W. Roberts et al., "Impaired cardiac efficiency and increased fatty acid oxidation in insulin-resistant ob/ob mouse hearts," Diabetes, vol. 53, no. 9, pp. 2366-2374, 2004.

[97] J. Buchanan, P. K. Mazumder, P. Hu et al., "Reduced cardiac efficiency and altered substrate metabolism precedes the onset of hyperglycemia and contractile dysfunction in two mouse models of insulin resistance and obesity," Endocrinology, vol. 146, no. 12, pp. 5341-5349, 2005.

[98] W. C. Stanley, F. A. Recchia, and G. D. Lopaschuk, "Myocardial substrate metabolism in the normal and failing heart," Physiological Reviews, vol. 85, no. 3, pp. 1093-1129, 2005.

[99] P. Wang, S. G. Lloyd, H. Zeng, A. Bonen, and J. C. Chatham, "Impact of altered substrate utilization on cardiac function in isolated hearts from Zucker diabetic fatty rats," American Journal of Physiology Heart and Circulatory Physiology, vol. 288, no. 5, pp. H2102-H2110, 2005.

[100] X. L. Du, D. Edelstein, L. Rossetti et al., "Hyperglycemiainduced mitochondrial superoxide overproduction activates the hexosamine pathway and induces plasminogen activator inhibitor-1 expression by increasing Sp1 glycosylation," Proceedings of the National Academy of Sciences of the United States of America, vol. 97, no. 22, pp. 12222-12226, 2000.

[101] G. Ye, N. S. Metreveli, R. V. Donthi et al., "Catalase protects cardiomyocyte function in models of type 1 and type 2 diabetes," Diabetes, vol. 53, no. 5, pp. 1336-1343, 2004.

[102] X. Shen, S. Zheng, N. S. Metreveli, and P. N. Epstein, "Protection of cardiac mitochondria by overexpression of MnSOD reduces diabetic cardiomyopathy," Diabetes, vol. 55, no. 3, pp. 798-805, 2006.

[103] S. Boudina and E. D. Abel, "Mitochondrial uncoupling: a key contributor to reduced cardiac efficiency in diabetes," Physiology, vol. 21, no. 4, pp. 250-258, 2006.

[104] J. G. Duncan, J. L. Fong, D. M. Medeiros, B. N. Finck, and D. P. Kelly, "Insulin-resistant heart exhibits a mitochondrial biogenic response driven by the peroxisome proliferatoractivated receptor- $\alpha /$ PGC- $1 \alpha$ gene regulatory pathway," Circulation, vol. 115, no. 7, pp. 909-917, 2007.

[105] Z. Li, T. Zhang, H. Dai et al., "Involvement of endoplasmic reticulum stress in myocardial apoptosis of streptozocininduced diabetic rats," Journal of Clinical Biochemistry and Nutrition, vol. 41, no. 1, pp. 58-67, 2007.

[106] C. L. Williamson, E. R. Dabkowski, W. A. Baseler, T. L. Croston, S. E. Alway, and J. M. Hollander, "Enhanced apoptotic propensity in diabetic cardiac mitochondria: influence of subcellular spatial location," American Journal of Physiology Heart and Circulatory Physiology, vol. 298, no. 2, pp. H633-H642, 2010.

[107] C. E. Flarsheim, I. L. Grupp, and M. A. Matlib, "Mitochondrial dysfunction accompanies diastolic dysfunction in diabetic rat heart," American Journal of Physiology Heart and
Circulatory Physiology, vol. 271, no. 1, pp. H192H202, 1996.

[108] P. J. Oliveira, R. Seica, P. M. Coxito et al., "Enhanced permeability transition explains the reduced calcium uptake in cardiac mitochondria from streptozotocin-induced diabetic rats," FEBS Letters, vol. 554, no. 3, pp. 511-514, 2003.

[109] J. G. Duncan, "Mitochondrial dysfunction in diabetic cardiomyopathy," Biochimica et Biophysica Acta (BBA) - Molecular Cell Research, vol. 1813, no. 7, pp. 1351-1359, 2011.

[110] L. S. Jouaville, P. Pinton, C. Bastianutto, G. A. Rutter, and R. Rizzuto, "Regulation of mitochondrial ATP synthesis by calcium: evidence for a long-term metabolic priming," Proceedings of the National Academy of Sciences of the United States of America, vol. 96, no. 24, pp. 13807-13812, 1999.

[111] J. Fauconnier, J. T. Lanner, S. J. Zhang et al., "Insulin and inositol 1, 4,5-trisphosphate trigger abnormal cytosolic $\mathrm{Ca}^{2+}$ transients and reveal mitochondrial $\mathrm{Ca}^{2+}$ handling defects in cardiomyocytes of ob/ob mice," Diabetes, vol. 54, no. 8, pp. 2375-2381, 2005.

[112] F. Dong, X. Zhang, X. Yang et al., "Impaired cardiac contractile function in ventricular myocytes from leptin-deficient $o b /$ $o b$ obese mice," Journal of Endocrinology, vol. 188, no. 1, pp. 25-36, 2006.

[113] D. D. Belke, E. A. Swanson, and W. H. Dillmann, "Decreased sarcoplasmic reticulum activity and contractility in diabetic $d b / d b$ mouse heart," Diabetes, vol. 53, no. 12, pp. 32013208, 2004. 


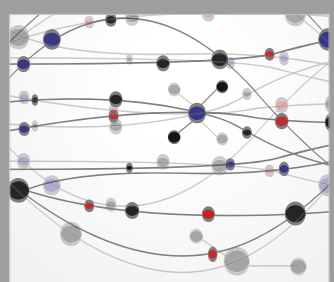

The Scientific World Journal
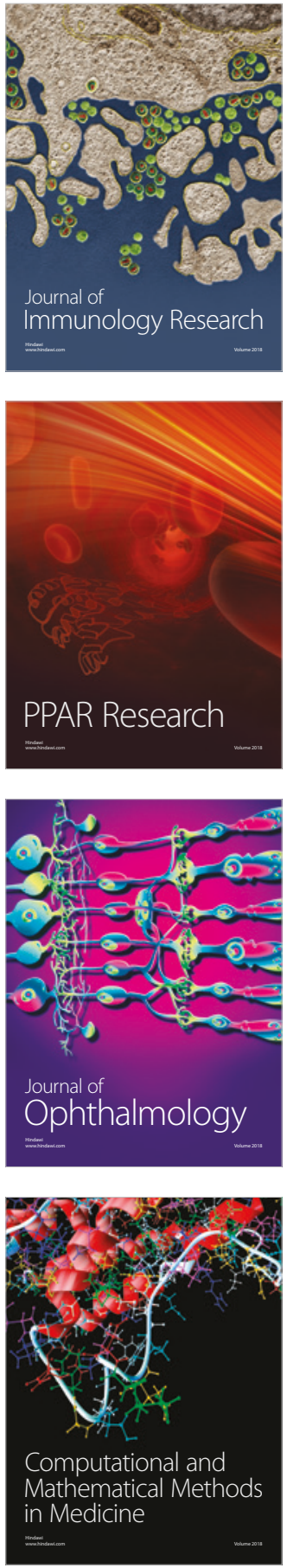

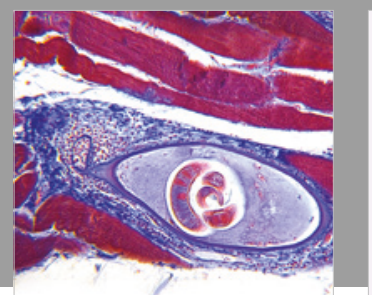

Gastroenterology Research and Practice

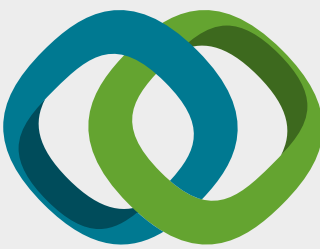

\section{Hindawi}

Submit your manuscripts at

www.hindawi.com
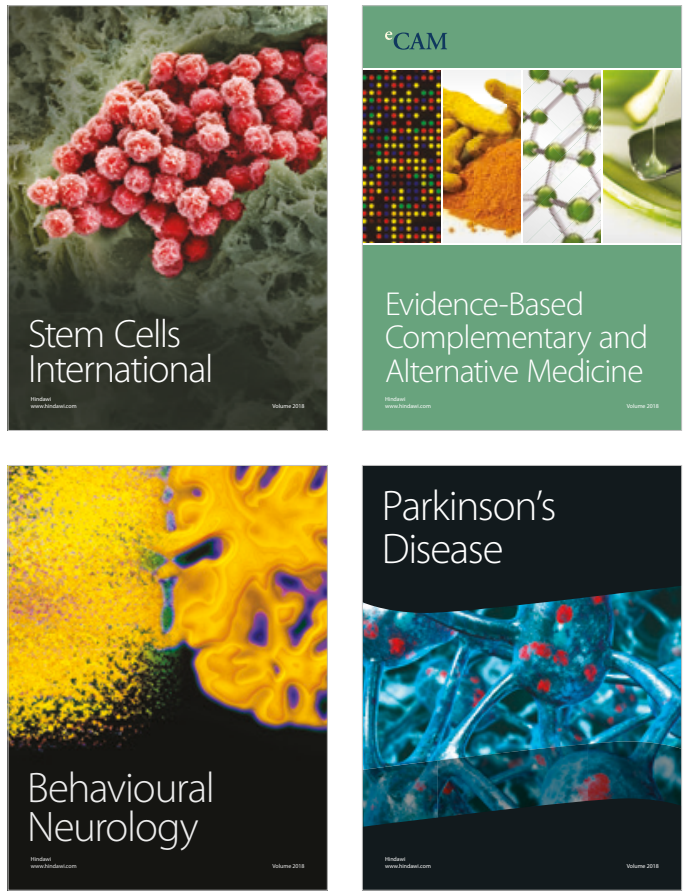

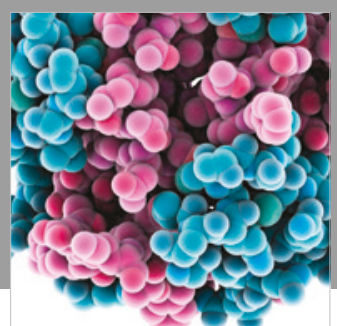

ournal of

Diabetes Research

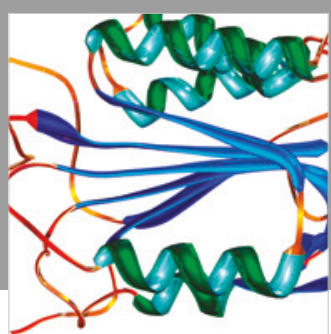

Disease Markers
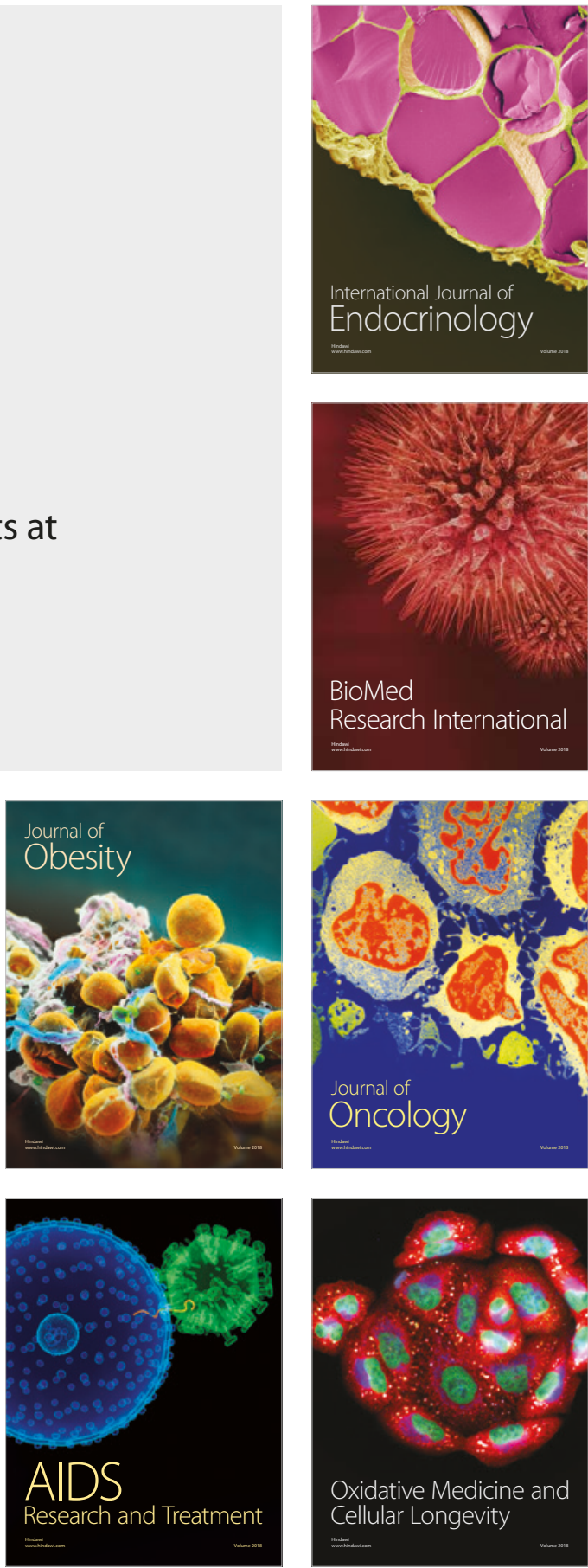